\title{
Fornix as an imaging marker for episodic memory deficits in healthy aging and in various neurological disorders
}

\author{
Vanessa Douet* and Linda Chang * \\ Department of Medicine, John A. Burns School of Medicine, University of Hawaii, Honolulu, HI, USA
}

\section{Edited by:}

Jean Mariani, Universite Pierre et

Marie Curie, France

Reviewed by:

Olivier Piguet, Neuroscience

Research Australia, Australia

Claudia Metzler-Baddeley, Cardiff

University, UK

*Correspondence:

Vanessa Douet and Linda Chang,

Department of Medicine, John A

Burns School of Medicine, The

Queen's Medical Center, 1356

Lusitana Street, UH Tower, Room

716, Honolulu, HI 96813, USA

e-mail: douet@hawaii.edu;

Ichang@hawaii.edu
The fornix is a part of the limbic system and constitutes the major efferent and afferent white matter tracts from the hippocampi. The underdevelopment of or injuries to the fornix are strongly associated with memory deficits. Its role in memory impairments was suggested long ago with cases of surgical forniceal transections. However, recent advances in brain imaging techniques, such as diffusion tensor imaging, have revealed that macrostructural and microstructural abnormalities of the fornix correlated highly with declarative and episodic memory performance. This structure appears to provide a robust and early imaging predictor for memory deficits not only in neurodegenerative and neuroinflammatory diseases, such as Alzheimer's disease and multiple sclerosis, but also in schizophrenia and psychiatric disorders, and during neurodevelopment and "typical" aging. The objective of the manuscript is to present a systematic review regarding published brain imaging research on the fornix, including the development of its tracts, its role in various neurological diseases, and its relationship to neurocognitive performance in human studies.

Keywords: fornix, development, aging, episodic memory, neuropsychiatric disorders, DTI

\section{INTRODUCTION}

The fornix is part of the limbic system that comprises cortical and subcortical structures. The cortical structures include cingulate and parahippocampal gyri, as well as the entorhinal cortex. The subcortical structures comprise the amygdalae, septal nuclei, nucleus accumbens, mammillary bodies, hypothalamus, anterior nucleus of the thalami, hippocampi and fornix.

The limbic system was first described by Pierre Paul Broca [1827-1880] (Broca, 1890) and was proposed to be the circuit of emotional experience and behavior by James W. Papez [1883-1958] (Papez, 1937). Later, its functions were linked to pleasure and reward, as well as memory and integration of memories (Rajmohan and Mohandas, 2007). Episodic memory belongs to the long-term memory system, and refers to conscious recollection of specific events (episodes) and contexts (time and place). Episodic memory frequently declines with aging and often becomes deficient in neurodegenerative diseases (Samson and Barnes, 2013) and psychiatric disorders (White et al., 2008). The critical subcortical structure for memory functions is the hippocampus (Penfield and Milner, 1958). As the major efferent white matter tract from the hippocampus, the fornix was frequently evaluated in relation to hippocampi and to memory impairments, especially to deficits in episodic memory (Yanike and Ferrera, 2014). Cumulative data from structural and diffusion tensor imaging (DTI) studies suggest that forniceal measures correlate with episodic memory performance in various neuropathological conditions, as well as during "typical" brain development and brain aging. The fornix appears to be a robust imaging predictor of episodic memory performance, independent of age and the etiology that may affect the integrity of the fornix.

In this review, we will focus on the findings from imaging studies of the fornix including its development, its implication in cognitive performance, and the structural changes associated with typical aging and neurodegenerative disorders. After a brief description of its anatomy, we will summarize the studies conducted on the forniceal formation across the lifespan, particularly those assessed by DTI which provided much new knowledge in our understanding of the fornix. We will then concentrate on diseases that may lead to an impaired or underdeveloped fornix and its likely consequences on cognitive performance, particularly in episodic memory.

\section{MATERIALS AND METHODS}

We searched in the PubMed ${ }^{\circledR}$ database for relevant publications during the last decade (last update on 2014 November 15th). Our search terms included "MRI," "DTI," diseases of interest, "aging," "development," "cognition," "memory" in combination with "fornix." 482 results were obtained. We screened the abstracts and included only the papers that were original, published in English and referred to human research. However, the most important selection criterion was that the studies explicitly reported imaging findings of the fornix. Conference abstracts and case reports were excluded. After screening all relevant studies and excluding those papers not fulfilling the inclusion criteria, we evaluated 143 studies in further detail. 


\section{ANATOMY OF THE FORNIX (FIGURE 1)}

The fornix of the brain is a C-shaped structure that projects from the posterior hippocampus to the septal area and hypothalamus. As the hippocampus terminates near the splenium of the corpus callosum, the fimbria becomes a detached bundle, the crus of the fornix. The two crura merge medially to form the body of the fornix. At the interventricular foramen, the body of the fornix diverges into the two adjacent columns that pass through the middle of the hypothalamus toward the mammillary bodies (Figure 1A).

The fornix is the largest efferent pathway from the hippocampus, and belongs to the "Papez circuit," which is also referred to as the limbic system. Forniceal fibers from the forebrain project to the anterior nucleus of the thalami, the mammillary bodies, hypothalamus, the septal nuclei and the ventral striata. Some fibers of the precommissural fornix spread beyond the septal nuclei and the ventral striata, and reach the orbital and anterior cingulate cortices. Forniceal fibers also contact the entorhinal cortex, amygdalae and back-project to the posterior cingulate gyrus (Nolte, 2009). The Papez circuit, or the limbic system, is involved in learning, memory, emotion and social behavior (King et al., 2013).

\section{NORMAL DEVELOPMENT AND AGING OF THE FORNIX (TABLE 1)}

On T1-weighted MRI, the left and right columns of the fornix are difficult to delineate, and are mainly treated as a single central structure that diverges into both cerebral hemispheres. Forniceal changes are often associated with abnormalities in surrounding structures, resulting in structural distortions that are difficult to assess. However, DTI can differentiate more easily the fornix from surrounding structures, and can quantify microstructural changes within the fornix. DTI characterizes the three-dimensional diffusion of water molecules and provides information on the integrity of tissue microstructures. The fractional anisotropy (FA) value indicates the architectural degree of the tissue, which may be influenced by the amount of myelination, the coherence of axonal fibers, or a combination of both, while the mean diffusivity (MD) value is a measure of the overall averaged water diffusion within a volume of tissue. For instance, a lower than typical FA observed during development of healthy children might indicate hypomyelination or slower growth of the axons, while a decline in FA might reflect either demyelination or a decline in the number of myelinated axonal fibers, or both. An increase in MD is associated with either neuronal damage or degeneration of microstructural barriers such as cell membranes. Loss of myelin typically increases radial diffusivity (RD), whereas axial diffusivity $(\mathrm{AxD})$ may be a more specific marker of axonal damage (Song et al., 2002, 2003).

Recently, the development of the fornix across the lifespan has become an active area of investigation because of the quality of visualization which is possible with DTI. However, only a small minority of these studies was conducted longitudinally (Table 1).

On the post-mortem human fetal brain, the fornix can be identified on MRI as early as 10 weeks of gestation (Rados et al., 2006). DTI techniques showed that the fornix is one of the most prominent tracts in the fetal brain and its entire tract is fully formed by 13 gestational weeks (Huang et al., 2006, 2009).
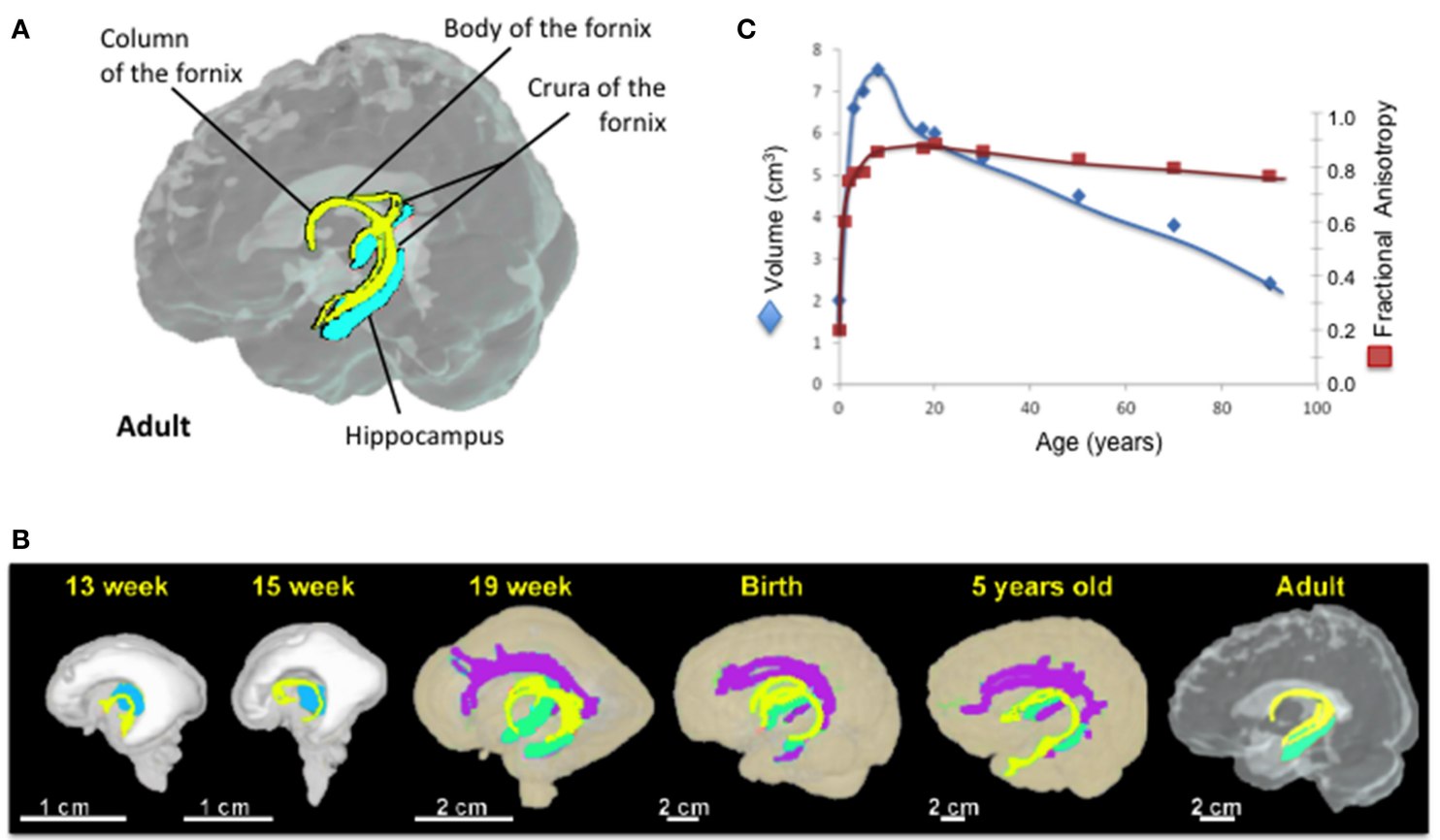

FIGURE 1 | The fornix across lifespan. (A) Anatomy of the fornix in the adult brain. Courtesy of Dr. Kenichi Oishi. (B) 3D reconstruction of the developmental tract of the fornix from 13 weeks of gestational age to adulthood.
(C) Developmental trajectories of forniceal volume (blue) and FA (red) from birth to 90 years old. (Adapted from Huang et al., 2006 and Huang et al., 2009). Yellow, the fornix; Green, the hippocampus; Purple, cingulum; Blue, Thalamus. 
Table 1 | Fornix metrics across the lifespan.

\begin{tabular}{|c|c|c|c|c|}
\hline Authors & $\begin{array}{l}\text { Subjects [age, M(male), } \\
F(\text { female })]\end{array}$ & Imaging Parameters & Image Analysis & Fornix-related Findings \\
\hline Rados et al., 2006 & $\begin{array}{l}16 \text { post-mortem fetal brains } \\
\text { (10-30 weeks gestation) }\end{array}$ & $\begin{array}{l}\text { T1 and T2 weighted MRI } \\
\text { Nissl-staining }\end{array}$ & Visualization & Fornix at 10 weeks of gestational age. \\
\hline Huang et al., 2006 & $\begin{array}{l}3 \text { post-mortem fetal brains } \\
\text { (19-20 weeks gestation) } \\
3 \text { female newborns } \\
3 \text { children (5-6 years, 2M, 1F) }\end{array}$ & $\begin{array}{l}4.7 \mathrm{~T} \text { (postmortem fœtus), } 7 \\
\text { directions } \\
1.5 \mathrm{~T} \text { (living subjects), } 30 \\
\text { directions, } 1.88 \mathrm{~mm} \text { slice } \\
\text { (newborns) and } 2.3 \mathrm{~mm} \text { slice } \\
\text { (children) }\end{array}$ & $\begin{array}{l}\text { Tractography, } 4 \\
\text { tracts, } 7 \text { ROls }\end{array}$ & $\begin{array}{l}\text { Fornix such as cingulum already } \\
\text { prominent during fetal stage, as early as } \\
19 \text { weeks of gestational age. }\end{array}$ \\
\hline Huang et al., 2009 & $\begin{array}{l}30 \text { post-mortem fetal brains } \\
\text { (13-22 weeks gestation); } 3 \\
\text { brains per week }\end{array}$ & $\begin{array}{l}11.7 \mathrm{~T}(13-16 \text { weeks), } \\
200-400 \mu \mathrm{m} \text { slice } \\
4.7 \mathrm{~T}(\geq 17 \text { weeks), } \\
300-600 \mu \mathrm{m} \text { slice, } 6 \\
\text { directions }\end{array}$ & 4 tracts and $7 \mathrm{ROIs}$ & $\begin{array}{l}\text { Fornix is the major tract at } 13 \text { weeks of } \\
\text { gestational age although it is a small } \\
\text { tract in adults }\end{array}$ \\
\hline $\begin{array}{l}\text { Hermoye et al., } \\
2006\end{array}$ & $\begin{array}{l}30 \text { children }[16 \pm 16 \text { months } \\
(0-4.5 \text { years), } 17 \mathrm{M}, 13 \mathrm{~F}]\end{array}$ & $\begin{array}{l}1.5 \mathrm{~T}, 32 \text { directions, } 1.9 \mathrm{~mm} \\
\text { slice (newborns) and } 2.3 \mathrm{~mm} \\
\text { slice (children) }\end{array}$ & $12 \mathrm{ROls}$ & $\begin{array}{l}\text { Fornix present at birth and prominent } \\
\text { compared to other brain structures }\end{array}$ \\
\hline Douet et al., 2014 & $\begin{array}{l}972 \text { children }[12.03 \pm 3.6 \\
\text { (3-20) years, } 509 \text { boys, } 463 \\
\text { girls] }\end{array}$ & $\begin{array}{l}3 \text { T scanners }(n=10), 30 \\
\text { directions, } 2.5 \mathrm{~mm} \text { slice }\end{array}$ & 5 ROls & $\begin{array}{l}\uparrow F A \text { with age (max at } 14.8 \text { years) then } \\
\text { plateau } \\
\uparrow \text { volume with age (max at } 12.6 \text { years) } \\
\text { then decrease slightly } \\
\uparrow \text { volume } \alpha \uparrow \text { episodic memory } \\
\uparrow F A \text { and } \downarrow \text { volume } \alpha \downarrow \text { episodic memory } \\
\text { in children with NRG1-TT-risk alleles for } \\
\text { schizophrenia and psychosis }\end{array}$ \\
\hline $\begin{array}{l}\text { Rudebeck et al., } \\
2009\end{array}$ & $\begin{array}{l}25 \text { Healthy Controls }[25.3 \pm \\
2.9(22-31) \text { years, } 14 \mathrm{M}, 9 \mathrm{~F}]\end{array}$ & $\begin{array}{l}3 \text { T, Diffusion-weighted } \\
\text { imaging }\end{array}$ & TBSS, VBM, 1 ROI & $\begin{array}{l}\uparrow F A \alpha \uparrow \text { episodic memory (recollection) } \\
\text { Spatial recognition FA }\end{array}$ \\
\hline Lebel et al., 2012 & $\begin{array}{l}403[31.3 \pm 21.5(5-83) \text { years, } \\
195 \mathrm{M}, 208 \mathrm{~F}]\end{array}$ & 1.5 T, 6 directions, $3 \mathrm{~mm}$ slice & Tractography & $\begin{array}{l}\text { Inverted U-shaped curve of FA with age } \\
\text { (max at } 19.5 \text { years old); U-shaped curve } \\
\text { for diffusivities (MD, RD, AxD) with age } \\
\text { (min } \sim 17.5 \text { years old); Inverted U-shaped } \\
\text { curve for volume (max } 21.3 \text { years) }\end{array}$ \\
\hline Sala et al., 2012 & $\begin{array}{l}84 \text { Healthy controls [ } 44 \\
(13-70) \text { years, 36M, 48F] }\end{array}$ & $\begin{array}{l}1.5 \mathrm{~T}, 12 \text { directions, } 4 \mathrm{~mm} \\
\text { slice }\end{array}$ & $\begin{array}{l}\text { Automated } \\
\text { atlas-based ROls }\end{array}$ & $\begin{array}{l}\text { Inverted U-shaped curve of FA with age; } \\
U \text {-shaped curve for MD } \\
\uparrow A x D \text { and } R D \text { and } \downarrow \text { volume with age }\end{array}$ \\
\hline Giorgio et al., 2010 & $\begin{array}{l}66 \text { adults }[31 \mathrm{M}, 35 \mathrm{~F}]-35 \\
\text { young }[23-40 \text { years, } 16 \mathrm{M} \text {, } \\
21 \mathrm{~F}], 19 \text { middle-age }[41-60 \\
\text { years, } 9 \mathrm{M}, 10 \mathrm{~F}], 10 \text { older } \\
\text { [60-82 years, 6M, 4F]- }\end{array}$ & $1.5 \mathrm{~T}, 60$ directions, $2.5 \mathrm{~mm}$ & TBSS, VBM & $\begin{array}{l}\downarrow \text { volume in older adults compared to } \\
\text { young and mid-adults }\end{array}$ \\
\hline $\begin{array}{l}\text { Michielse et al., } \\
2010\end{array}$ & $\begin{array}{l}69 \text { adults }[46.9 \pm 17.8(22-84) \\
\text { years, } 17 \mathrm{M}, 52 \mathrm{~F}]\end{array}$ & 1.5 T, 6 directions, $2 \mathrm{~mm}$ slice & $\begin{array}{l}9 \text { ROls } \\
\text { Tractography } \\
\text { (crus only) }\end{array}$ & $\begin{array}{l}\text { Linear } \downarrow \text { volume and FA with age } \\
\text { Linear } \downarrow \text { AxD and MD with age and RD } \leftrightarrow \\
\text { No asymmetry with age }\end{array}$ \\
\hline
\end{tabular}


Table 1 | Continued

\begin{tabular}{|c|c|c|c|c|}
\hline Authors & $\begin{array}{l}\text { Subjects [age, } M(\text { male }) \\
\text { F(female })]\end{array}$ & Imaging Parameters & Image Analysis & Fornix-related Findings \\
\hline Lee et al., 2009 & $\begin{array}{l}31 \text { adults }[36(19-62) \text { years, } \\
15 \mathrm{M}, 16 \mathrm{~F}]\end{array}$ & $\begin{array}{l}3 \text { T, } 32 \text { directions, } 2.5 \mathrm{~mm} \\
\text { slice }\end{array}$ & 14 Manual ROls & $\begin{array}{l}\text { No age-related changes in FA and ADC. } \\
\text { No sex-difference }\end{array}$ \\
\hline $\begin{array}{l}\text { Stadlbauer et al., } \\
2008\end{array}$ & $\begin{array}{l}38 \text { adults }[49.6 \pm 20.1 \\
(18-88) \text { years, } 18 \mathrm{M}, 20 \mathrm{~F}]\end{array}$ & $3 \mathrm{~T}, 6$ directions, $1.9 \mathrm{~mm}$ slice & Tractography & $\begin{array}{l}\downarrow \text { FA with age }(-2.1 \% \text { per decade }), \\
\downarrow \text { number of tract } \\
\uparrow M D(4.2 \% \text { per decade })\end{array}$ \\
\hline Pagani et al., 2008 & $\begin{array}{l}84 \text { adults [44 (13-70) years, } \\
36 \mathrm{M}, 48 \mathrm{~F}]\end{array}$ & $\begin{array}{l}1.5 \mathrm{~T}, 12 \text { directions, } 4 \mathrm{~mm} \\
\text { slice }\end{array}$ & $\begin{array}{l}\text { VBM } \\
11 \text { clusters }\end{array}$ & $\downarrow$ volume with age \\
\hline Zahr et al., 2009 & $\begin{array}{l}24 \text { adults- } 12 \text { young }[25.5 \pm \\
4.34(29-33) \text { years, } 12 \text { older } \\
\text { adults }[77.67 \pm 4.94(67-84) \\
\text { years- }\end{array}$ & $\begin{array}{l}3 \mathrm{~T}, 15 \text { directions, } 2.5 \mathrm{~mm} \\
\text { slice }\end{array}$ & $\begin{array}{l}\text { Tractography } \\
8 \text { ROls }\end{array}$ & $\begin{array}{l}\downarrow F A \text { and } \uparrow A D C, R D \text { and } A x D \text { in older } \\
\text { adults compared to young. } \uparrow F A \text { and } \\
\downarrow A D C \text { correlate with } \uparrow \text { working memory, } \\
\text { motor, problem solving scores }\end{array}$ \\
\hline Sullivan et al., 2010 & $\begin{array}{l}120 \text { adults }[48.3 \pm 14.4 \\
(20-81) \text { years, } 55 \mathrm{M}, 65 \mathrm{~F}]\end{array}$ & 1.5 T, 6 directions, $4 \mathrm{~mm}$ slice & Tractography & $\begin{array}{l}\uparrow A D C, R D \text {, and } A x D \text { with age } \\
\text { No changes in FA }\end{array}$ \\
\hline $\begin{array}{l}\text { Burzynska et al., } \\
2010\end{array}$ & $\begin{array}{l}143 \text { adults-80 young }[25.7 \pm \\
3.2(20-32) \text { years, } 45 \mathrm{M}, 35 \mathrm{~F}] \\
63 \text { older }[64.8 \pm 2.9(60-71) \\
\text { years, 34M, 29F]- }\end{array}$ & $\begin{array}{l}1.5 \mathrm{~T}, 12 \text { directions, } 2.5 \mathrm{~mm} \\
\text { slice }\end{array}$ & $\begin{array}{l}\text { TBSS, VBM } \\
\text { (body/colum and } \\
\text { crus) }\end{array}$ & $\begin{array}{l}\text { Body/column: } \downarrow F A \text { and } \uparrow \text { diffusivities } \\
\text { (MD, RD, and } A x D \text { ) in older adults } \\
\text { compared to young } \\
\text { Crus: } \downarrow F A \text { and } \uparrow R D \text { and } A x D \text { in older } \\
\text { adults compared to young }\end{array}$ \\
\hline Jang et al., 2011 & $\begin{array}{l}60 \text { adults }[49.2(20-78) \text { years, } \\
\text { 30M, 30F]- young adults: } \\
\text { 20-39 years, mid-adults: } \\
\text { 40-59 years, older adults: } \\
\text { 60-79 years- }\end{array}$ & $\begin{array}{l}1.5 \mathrm{~T}, 32 \text { directions, } 2.3 \mathrm{~mm} \\
\text { slice }\end{array}$ & $\begin{array}{l}\text { Tractography } \\
3 \text { ROIs (body, } \\
\text { column and crus = } \\
\text { 3parts) }\end{array}$ & $\begin{array}{l}\downarrow F A \text { and } \uparrow A D C \text { with age } \\
\downarrow \text { number of tract }\end{array}$ \\
\hline Sasson et al., 2013 & $\begin{array}{l}52 \text { adults [51 (25-82 years), } \\
20 \mathrm{M}, 32 \mathrm{~F}]\end{array}$ & $\begin{array}{l}3 \mathrm{~T}, 19 \text { directions, } 2.5 \mathrm{~mm} \\
\text { slice }\end{array}$ & Tractography, VBA & $\downarrow F A$ and $\uparrow A x D$ with age \\
\hline Pelletier et al., 2013 & $\begin{array}{l}129 \text { Healthy controls }[73.9 \\
\text { years, } \geq 65 \text { years, 68M, 61F] }\end{array}$ & $\begin{array}{l}3 \text { T, } 21 \text { directions, } 2.5 \mathrm{~mm} \\
\text { slice }\end{array}$ & TBSS and 2 ROIs & $\begin{array}{l}\downarrow F A \text { with age; FA as a predictor of age } \\
\uparrow F A \alpha \uparrow \text { hippocampal volume }\end{array}$ \\
\hline $\begin{array}{l}\text { Vernooij et al., } \\
2008\end{array}$ & $\begin{array}{l}832 \text { Healthy controls }[73.9 \pm \\
4.8 \text { years, } \geq 55 \text { years, } 413 \mathrm{M}, \\
419 \mathrm{~F}]\end{array}$ & $\begin{array}{l}1.5 \mathrm{~T}, 25 \text { directions, } 2.5 \mathrm{~mm} \\
\text { slice }\end{array}$ & TBSS & $\downarrow$ Volume, $\downarrow F A, \uparrow A x D$ and $R D$ with age \\
\hline $\begin{array}{l}\text { Metzler-Baddeley } \\
\text { et al., } 2011\end{array}$ & $\begin{array}{l}46 \text { adults }[67.9 \pm 8.6(53-93) \\
\text { years, } 21 \mathrm{M}, 25 \mathrm{~F}]\end{array}$ & $\begin{array}{l}3 \text { T, } 30 \text { directions, } 2.4 \mathrm{~mm} \\
\text { slice }\end{array}$ & $\begin{array}{l}\text { Tractography } \\
4 \text { ROIs }\end{array}$ & $\begin{array}{l}\downarrow F A \text { with age } \\
\uparrow F A \alpha \uparrow \text { episodic memory }\end{array}$ \\
\hline Fletcher et al., 2013 & $\begin{array}{l}102[73 \pm 6.4 \text { years, } 20 \\
\text { converters to } \mathrm{MCl} \text {, and } 82 \\
\text { non converters] }\end{array}$ & $\begin{array}{l}1.5 \mathrm{~T}, 6 \text { directions, } 1.5 \mathrm{~mm} \\
\text { slice }\end{array}$ & $\begin{array}{l}1 \text { manual ROI (body } \\
\text { only) }\end{array}$ & $\downarrow F A$ and volume with age \\
\hline Yasmin et al., 2009 & $\begin{array}{l}100 \text { adults }[58 \pm 11(40-84) \\
\text { years, } 50 \mathrm{M}, 50 \mathrm{~F}]\end{array}$ & $\begin{array}{l}3 \text { T, } 13 \text { directions, } 2.5 \mathrm{~mm} \\
\text { slice }\end{array}$ & $8 \mathrm{ROls}$ & $\downarrow F A$ and $\uparrow M D$ with age \\
\hline
\end{tabular}

$\alpha$, correlate; T, Tesla; ROI, Region of Interest; FA, fractional anisotropy; MD, Mean Diffusivity; AxD, Axial diffusivity; RD, Radial diffusivity.

VBM, voxel based morphometry; TBSS, Tract based spatial statistics.

At birth, the fornix is more prominent compared to the other brain fiber tracts and this phenotype is retained during infancy (Hermoye et al., 2006; Dubois et al., 2008). The development of fornix is thought to be completed by age 5 years (Hermoye et al., 2006; Dubois et al., 2008; Lebel et al., 2012) (Figure 1B). However, three cross-sectional (Lebel et al., 2012; Sala et al., 2012; Douet et al., 2014) and two longitudinal (Simmonds et al., 2014) DTI studies that investigated the volume and/or white matter integrity and density of the fornix showed its development through adolescence, and further age-related changes of the fornix throughout the lifespan (Figure 1C). Forniceal (body/column and crescent) FA exhibits an inverted U-shaped curve while the MD shows 
a U-shaped curve, and both peak at late adolescence (maximum at 19.5 years for FA and minimum at 17.8 years for MD) (Lebel et al., 2012; Sala et al., 2012). A recent longitudinal study reported no significant changes in the developmental trajectory of FA of the forniceal body/column, while FA in its crescent portion continues to increase during adolescence [13-16 years] (Simmonds et al., 2014). These findings suggest that the agerelated changes of FA observed in the cross-sectional studies were primarily due to changes in the crescent rather than in the body/column of the fornix. Before peaking at late adolescence, the fornix has the steepest age-dependent increase in MD amongst all major tracts (Lebel et al., 2012; Sala et al., 2012), with AxD and $\mathrm{RD}$ showing more than $2 \%$ change per year (Simmonds et al., 2014). Interestingly, age-related increase of $\mathrm{AxD}$, i.e., accelerated prunning, was found in the left hemisphere but not in the right hemisphere during childhood and adolescence (Simmonds et al., 2014). Similarly, asymmetric atrophy of the hippocampus and fornix were reported in several neurological disorders such as schizophrenia (Crow et al., 1989; DeLisi et al., 1997; McDonald et al., 2000; Chance et al., 2005; Mitchell and Crow, 2005; Mitelman et al., 2005), bipolar disorders (Brisch et al., 2008), temporal lobe epilepsy (Baldwin et al., 1994; Hori, 1995; Kim et al., 1995; Kuzniecky et al., 1999), and in some patients with traumatic brain injury (Tate and Bigler, 2000; Tomaiuolo et al., 2004). Therefore, finding a more sensitive neuroimaging marker to assess the forniceal lateralization, such as $\mathrm{AxD}$ of the fornix, may be useful for early diagnosis of these disorders.

Prior to adulthood, the forniceal volume also exhibits an inverted U-shaped curve with age, and thereafter an agedependent decrease in the volume in both longitudinal and cross-sectional studies (Pagani et al., 2008; Giorgio et al., 2010; Michielse et al., 2010; Lebel et al., 2012; Sala et al., 2012; Fletcher et al., 2013).

During adulthood, the white matter integrity and density of the fornix typically decrease with age across DTI studies (Stadlbauer et al., 2008; Lee et al., 2009; Yasmin et al., 2009; Michielse et al., 2010; Sullivan et al., 2010; Lebel et al., 2012; Sala et al., 2012; Fletcher et al., 2013; Sasson et al., 2013). The majority of the studies found age-related decreases of the forniceal FA (Stadlbauer et al., 2008; Yasmin et al., 2009; Zahr et al., 2009; Burzynska et al., 2010; Michielse et al., 2010; Jang et al., 2011; Metzler-Baddeley et al., 2011; Lebel et al., 2012; Sala et al., 2012; Fletcher et al., 2013; Pelletier et al., 2013; Sasson et al., 2013), and only two studies showed no changes with age (Lee et al., 2009; Sullivan et al., 2010). Findings on the diffusivities ( $\mathrm{MD}, \mathrm{AxD}$ and $\mathrm{RD}$ ) are less consistent and varied depending on the region of interest (crus, body/column or the entire fornix). While the majority of the studies found diffusivities (MD, AxD and RD) of the fornix increase with age (Stadlbauer et al., 2008; Yasmin et al., 2009; Zahr et al., 2009; Burzynska et al., 2010; Sullivan et al., 2010; Jang et al., 2011; Lebel et al., 2012; Sala et al., 2012; Sasson et al., 2013; Simmonds et al., 2014), several studies reported either age-related decrease of $\mathrm{MD}$ and $\mathrm{AxD}$ (Michielse et al., 2010) or no changes in the fornix with age for MD (Lee et al., 2009) and RD (Michielse et al., 2010) across the age span of 10 to 80 years. White matter maturation follows sex-specific differential trajectories (Westerhausen et al., 2004; Schmithorst et al., 2008; Asato et al., 2010). Girls showed maturation of white matter integrity earlier than boys (Asato et al., 2010). In particular, girls showed greater age-dependent increase of MD in associative regions compared to boys. Furthermore, tendencies for age-related increase of FA were found in the right hemisphere for girls but in the left hemisphere for boys. These sex-specific brain differences parallel the pubertal changes that occur during adolescence, suggesting that hormonal changes might influence white matter maturity. However, the few studies that examined the relationships between physical pubertal maturity and circulating hormones on white matter maturation were underpowered by sample size(Peper et al., 2008, 2009). Nevertheless, discrepancies on diffusivities between DTI studies are not due to differences in age range and sex distribution, since they are similar across all of these studies. The image processing methods for these studies are also similar between those that showed conflicting results. Therefore, sample size or inter-subject variations might have contributed to the different findings regarding the age-related changes in FA and MD.

Overall, the fornix is one of the earliest white matter tracts to mature. After its maturation peaks during late adolescence, the fornix begins to "atrophy" throughout the remainder of the lifespan. However, "pruning" rather than degenerative processes likely contribute to the early decreases in forniceal volume. More detail anatomical assessments of the fornix (column, body, and crus) and more systematic evaluations across a larger age range, followed longitudinally, are needed to better characterize the developmental trajectories of the fornix.

\section{Relationship with cognition}

Fibers from the fornix comprise the main cholinergic input to the hippocampi and major efferent pathways from the hippocampi to the anterior thalamic nuclei, mammillary bodies, striata, and prefrontal cortices. These anatomical connections are involved in memory networks, which demonstrate that the fornix plays a critical and central role in memory tasks, particularly episodic memory. However, few studies investigated the relationships between forniceal metrics and memory tasks during typical development and aging. During childhood [3-20 years], larger forniceal volume was correlated with better episodic memory scores in healthy children. But this relationship was reversed in those carrying the NRG1-T-risk alleles for schizophrenia and psychosis (Douet et al., 2014). During young adulthood [22-31 years], greater FA in the fornix was associated with better episodic memory scores, especially with spatial recognition (Rudebeck et al., 2009). Similarly, across studies of young adults and older adults, forniceal FA correlated positively with working memory (Zahr et al., 2009), episodic memory (Rudebeck et al., 2009), and with both verbal and visual recall tasks (Rudebeck et al., 2009; Zahr et al., 2009; Metzler-Baddeley et al., 2011). A 4-year longitudinal follow-up study of healthy older adults found that lower forniceal volume and higher $\mathrm{AxD}$ at baseline predicted conversion to cognitive impairments (mild cognitive impairment or dementia) (Fletcher et al., 2013). Therefore, volumetric and white matter changes of the fornix appear to be effective biomarkers to validate or corroborate with memory performance across the lifespan, and to predict hippocampal function (Aggleton et al., 
2000; Rudebeck et al., 2009; Fletcher et al., 2013; Pelletier et al., 2013).

\section{FORNIX AS A PREDICTOR OF MEMORY DEFICITS}

Early studies in humans did not report associated memory deficits after lesion of the fornix (Garcia-Bengochea and Friedman, 1987). More recent studies, however, consistently reported deficits in several cognitive abilities, especially in episodic memory, in patients with injuries to the fornix (Gaffan et al., 1991; Squire and Zola-Morgan, 1991; Aggleton et al., 2000). Moreover, as part of the limbic system, fornix degeneration may precede hippocampal dysfunction, and may predict conversion to cognitive impairment better than hippocampal atrophy (Fletcher et al., 2013). Hence, assessments of the fornix have recently become a major research focus in determining its role in neurological disorders that are associated with memory impairments.

\section{Alzheimer disease and dementia syndromes (Table 2)}

Alzheimer disease (AD) and mild cognitive impairment (MCI) can be distinguished from normal aging by the different clinical syndromes (Petersen et al., 2001). MCI includes amnestic MCI (aMCI) and non-amnestic MCI (naMCI) (Petersen, 2004), depending on the memory impairment features. While naMCI patients tend to develop frontotemporal dementia or other types of dementias with broader cognitive deficits, aMCI patients are at risk for Alzheimer's disease (Mielke et al., 2014). In the US population, the prevalence of MCI ranges from 3 to $19 \%$ depending on the studies. About $40 \%$ of MCI patients will develop AD or other dementias, while most of MCI patients stay stable, and some even revert to a healthy control diagnosis (Mielke et al., 2014). Therefore, understanding prodromal $\mathrm{AD}$ and predicting accurately when MCI will convert to dementia can lead to early diagnosis and prevention of dementia when effective preventive strategies become available.

The neuropathology of $\mathrm{AD}$ is characterized by the presence of extracellular beta-amyloid plaques and intracellular neurofibrillary tangles that both lead to neuronal dysfunction and apoptosis (Bossy-Wetzel et al., 2004). Neurofibrillary tangles result from the intracellular oligomerization of the microtubule-associated protein Tau. The deposition of neurofibrillary tangles begins primarily in the limbic system structures, initially in the entorhinal cortex and the medial temporal regions, then progressively spread across the cerebral cortex. Hippocampal and entorhinal cortical atrophy assessed with MRI is well documented in patients with $\mathrm{AD}$ (Teipel et al., 2013), and in many with MCI (Pihlajamaki et al., 2009). Furthermore, this observation has extended the investigation of all limbic structures in relation to disease progression and cognitive performance.

The fornix is atrophied in MCI and AD patients compared to healthy controls, (Callen et al., 2001; Copenhaver et al., 2006; Ringman et al., 2007; Hattori et al., 2012) as confirmed by a longitudinal follow-up study (Douaud et al., 2013). Furthermore, in a large cohort of $79 \mathrm{aMCI}$ and 204 healthy controls (HC), the volume of the crus of the fornix more specifically discriminated between MCI and HC (Cui et al., 2012).

Decreased FA of the fornix, on DTI, was found to be more sensitive than decreases in volume and/or area, on structural MRI, for predicting $\mathrm{AD}$ progression, since decreased FA preceded the atrophy more than two years prior to conversion from MCI to AD (Douaud et al., 2013). AD patients had lower FA (Liu et al., 2011b; Metzler-Baddeley et al., 2012) and higher MD and RD in the fornix compared to healthy controls (Mielke et al., 2009; Stricker et al., 2009; Liu et al., 2011b; Hattori et al., 2012; Huang et al., 2012; Oishi et al., 2012; Nowrangi et al., 2013; Zhuang et al., 2013), and at disease onset as defined by comparison between MCI and/or early onset AD patients (Mielke et al., 2009; Zhuang et al., 2010; Liu et al., 2011b; Oishi et al., 2012; Canu et al., 2013; Douaud et al., 2013; Nowrangi et al., 2013). A similar phenotype of lower FA in the fornix was found also in patients with genetically inherited dementias in comparison to controls (Ringman et al., 2007). Longitudinal studies showed that the magnitude of age-related changes of DTI metrics is similar between AD, MCI and healthy controls (Mielke et al., 2009, 2012; Oishi et al., 2012), suggesting that abnormal forniceal FA and MD are likely to predict convertion from $\mathrm{MCI}$ to $\mathrm{AD}$.

Lower FA and higher diffusivity metrics in the fornix were associated also with worse performance on short- and longterm memory tasks and with clinical dementia evaluations in AD and MCI patients (Ringman et al., 2007; Mielke et al., 2009, 2012; Kantarci et al., 2011; Zhuang et al., 2013), as well as in healthy controls (Sexton et al., 2011; Oishi et al., 2012; Nowrangi et al., 2013). These cognitive measures showed deficits in verbal memory (i.e., California Verbal Learning Test, Hopkins Verbal Learning Test) and visual memory (Rey-Osterrieth Complex Figure Test), as well as in more global measures (MMSE and Clinical Dementia Rating).

Therefore, measurements of macro- and micro-structural changes in the fornix may provide preclinical surrogate markers to predict the development of Alzheimer disease and allow early treatment in these patients.

\section{Schizophrenia (SCZ) (Table 3)}

Clinical signs, brain imaging and genetic studies all contributed to the hypothesis that schizophrenia and psychiatric diseases are neurodevelopmental disorders (Rapoport et al., 2012) with neurodegenerative components (Vita et al., 2012). In addition, findings from postmortem and neuroimaging studies suggest that white matter maturation and myelination processes are disrupted in schizophrenia, which might trigger its symptoms (Heckers et al., 1991; Arnold et al., 1995) or lead to age-related white matter loss and cognitive decline (Chang et al., 2007; Kochunov and Hong, 2014). Brain abnormalities in SCZ patients occur in the paralimbic and temporolimbic regions (Kasai et al., 2003), which are involved in episodic memory. Incidentally, episodic memory impairment is one of the most consistent phenotype for schizophrenia (Schaefer et al., 2013). Since the fornix is part of the limbic system, and is involved in episodic memory, it has been evaluated with histopathology and brain imaging in SCZ patients.

Histopathologic studies showed that SCZ men, but not women, had greater than normal fiber density in the left fornix, suggesting sex and hemisphere specific alterations in the myelination of the fornix in schizophrenia (Chance et al., 1999). However, the fornix volume and cross-sectional area were found to be similar between SCZ patients and healthy adult controls in 
Table 2 | Forniceal macro- and micro-structure alterations in patients with Alzheimer's disease and mild cognitive impairments.

\begin{tabular}{|c|c|c|c|c|}
\hline Authors & $\begin{array}{l}\text { Subjects [Mean age } \pm S D \text { (age range), Male, } \\
\text { Female] }\end{array}$ & Image Acquisition & Image Analysis & Fornix-related Findings \\
\hline \multicolumn{5}{|c|}{ STRUCTURAL MRI STUDIES } \\
\hline Callen et al., 2001 & $\begin{array}{l}40 \mathrm{AD}[69.1 \pm 7.3(54.5-80) \text { years, } 20 \mathrm{M}, 20 \mathrm{~F}] \\
40 \mathrm{HC}[70.4 \pm 6.3(55.8-80.6) \text { years, 20M, 20F] }\end{array}$ & $\begin{array}{l}1.5 \mathrm{~T}, \mathrm{~T} 1 \text {-weighted } \\
\mathrm{MRI}, 1.5 \mathrm{~mm} \text { slice }\end{array}$ & $\mathrm{ROI}$ & Volume: $A D<H C$ \\
\hline $\begin{array}{l}\text { Copenhaver et al., } \\
2006\end{array}$ & $\begin{array}{l}16 \mathrm{AD}[75.6 \pm 6.9(63-86) \text { years, 7M, 9F }] \\
20 \mathrm{CC}[73.9 \pm 6.6(63-86) \text { years, 6M, 14F }] \\
20 \mathrm{MCl}[69.6 \pm 6.2(63-86) \text { years, 10M, 10F }] \\
20 \mathrm{HC}[71.3 \pm 5.7(63-86) \text { years, 6M, 14F }]\end{array}$ & $\begin{array}{l}1.5 \mathrm{~T}, \mathrm{~T} 1 \text {-weighted } \\
\mathrm{MRI}, 1.5 \mathrm{~mm} \text { slice }\end{array}$ & ROI (crus) & $\begin{array}{l}\text { Volume: } \mathrm{AD}<\mathrm{HC} \\
\downarrow \text { volume with age in all } \\
\text { groups }\end{array}$ \\
\hline \multicolumn{5}{|c|}{ DIFFUSION TENSOR STUDIES } \\
\hline Ringman et al., 2007 & $\begin{array}{l}12 \text { FADmc }[35 \pm 6.4 \text { years, } 2 M, 10 F] \\
8 \text { FADnc }[36 \pm 6.2 \text { years, } 1 M, 7 F]\end{array}$ & 1.5 T, 6 directions & $\mathrm{ROI}$ & $\begin{array}{l}\text { Area: FADmc }<\text { FADnc } \\
\text { FA: FADmc }<\text { FADnc } \\
\downarrow \text { FA } \propto \downarrow \text { all NPTs and } \uparrow \text { AD } \\
\text { severity }\end{array}$ \\
\hline Stricker et al., 2009 & $\begin{array}{l}16 \mathrm{AD}[77.3 \pm 9.0 \text { years, 8M, 8F] } \\
14 \mathrm{HC}[77.4 \pm 8.1 \text { years, 5M, 9F] }\end{array}$ & $\begin{array}{l}3 \mathrm{~T}, 15 \text { directions, } \\
3 \mathrm{~mm} \text { slice }\end{array}$ & TBSS & $\mathrm{FA}: \mathrm{AD}<\mathrm{HC}$ \\
\hline Mielke et al., 2009 & $\begin{array}{l}25 \mathrm{AD}[75.6 \pm 7.0 \text { years, } 18 \mathrm{M}, 7 \mathrm{~F}] \\
25 \mathrm{MCl}[75.8 \pm 5.3 \text { years, } 18 \mathrm{M}, 7 \mathrm{~F}] \\
25 \mathrm{HC}[74.3 \pm 7.1 \text { years, } 11 \mathrm{M}, 14 \mathrm{~F}]\end{array}$ & $\begin{array}{l}3 \mathrm{~T}, 30 \text { directions } \\
2.2 \mathrm{~mm} \text { slice }\end{array}$ & $\begin{array}{l}\text { ROI (body) } \\
\text { 3-month follow-up }\end{array}$ & $\begin{array}{l}\text { No difference longitudinally } \\
\text { (3 months) } \\
\text { Cross-sectionally } \\
\mathrm{FA}: \mathrm{MCl}>\mathrm{AD}<\mathrm{HC} \\
\text { In } \mathrm{MCl} \text { and } \mathrm{AD}: \downarrow \mathrm{FA} \propto \downarrow \\
\text { memory scores (on CVLT) } \\
\text { and } \downarrow \mathrm{CDR}\end{array}$ \\
\hline Sexton et al., 2010 & $\begin{array}{l}\text { 7AD }[68.1 \pm 9.6 \text { years, } 5 \mathrm{M}, 2 \mathrm{~F}] \\
8 \mathrm{MCl}[73.0 \pm 7.5 \text { years, } 3 \mathrm{M}, 5 \mathrm{~F}] \\
8 \mathrm{HC}[77.1 \pm 4.6 \text { years, } 3 \mathrm{M}, 5 \mathrm{~F}]\end{array}$ & $\begin{array}{l}1.5 \mathrm{~T}, 51 \text { directions, } \\
2.8 \mathrm{~mm} \text { slice }\end{array}$ & $\begin{array}{l}\text { TBSS and ROls } \\
\text { (Body and crus) }\end{array}$ & $\begin{array}{l}\uparrow F A \text { (Left_crus), } \downarrow \text { AxD } \\
\text { (Left_crus), } \downarrow M D \text { (crus) and } \\
\text { RD (crus) } \alpha \uparrow \text { episodic } \\
\text { memory factor (CVLT-R, } \\
\text { HVLT-R, RCFT) }\end{array}$ \\
\hline Zhuang et al., 2010 & $\begin{array}{l}96 \text { aMCl }[79.57 \pm 4.71(70-90) \text { years, 57M, 39F] } \\
69 \text { naMCl }[77.62 \pm 4.49(70-90) \text { years, } 21 \mathrm{M}, \\
48 \mathrm{~F}] \\
252 \mathrm{HC}[77.87 \pm 4.52(70-90) \text { years, } 106 \mathrm{M}, \\
146 \mathrm{~F}]\end{array}$ & $\begin{array}{l}3 \mathrm{~T}, 6 \text { directions } \\
3.5 \mathrm{~mm} \text { slice }\end{array}$ & TBSS & $\begin{array}{l}\mathrm{FA}: \text { aMCl }<\mathrm{HC} \\
\text { FA: discriminated } \sim 70 \% \\
\text { (aMCl vs. } \mathrm{HC} \text { ) }\end{array}$ \\
\hline Kantarci et al., 2011 & 149 MCl/71 HC [median 79 (52-95) years] & $\begin{array}{l}3 \mathrm{~T}, 21 \text { directions } \\
3.3 \mathrm{~mm} \text { slice }\end{array}$ & ROls and VBM & $\begin{array}{l}\uparrow F A \propto \uparrow \text { language function, } \\
\uparrow v i s u a l-s p a t i a l \text { processing }\end{array}$ \\
\hline Liu et al., $2011 b$ & $\begin{array}{l}17 \mathrm{AD}[76 \pm 7 \text { years, } 6 \mathrm{M}, 11 \mathrm{~F}] \\
27 \mathrm{MCl}[75 \pm 6 \text { years, } 15 \mathrm{M}, 12 \mathrm{~F}] \\
19 \mathrm{HC}[75 \pm 6 \text { years, } 11 \mathrm{M}, 8 \mathrm{~F}]\end{array}$ & $\begin{array}{l}1.5 \mathrm{~T}, 30 \text { directions } \\
5 \mathrm{~mm} \text { slice }\end{array}$ & TBSS & $\begin{array}{l}F A: A D<H C \\
F A: A D<M C l \text { in the right } \\
\text { fornix }\end{array}$ \\
\hline Cui et al., 2012 & $\begin{array}{l}79 \text { aMCl }[79.42 \pm 4.71 \text { years, 49M, 30F] } \\
204 \mathrm{HC}[77.65 \pm 4.37(67-90) \text { years, 85M, 119F] }\end{array}$ & $\begin{array}{l}3 \mathrm{~T}, 6 \text { directions } \\
3.5 \mathrm{~mm}\end{array}$ & $\mathrm{ROI}$ & $\begin{array}{l}\text { Crus discriminates between } \\
\mathrm{MCl} \text { and } \mathrm{HC}\end{array}$ \\
\hline Hattori et al., 2012 & $\begin{array}{l}20 \mathrm{AD}[74.6 \pm 5.7 \text { years, } 10 \mathrm{M}, 10 \mathrm{~F}] \\
22 \mathrm{iNPH}[77.3 \pm 4.9 \text { years, 10M, 12F } \\
20 \mathrm{HC}[73.9 \pm 6.0 \text { years, 7M, 13F }]\end{array}$ & $\begin{array}{l}1.5 \mathrm{~T}, 13 \text { directions } \\
3 \mathrm{~mm} \text { slice }\end{array}$ & Tractography & $\begin{array}{l}\text { Volume: iNPH }<A D<I H C \\
\text { FA: iNPH }<H C \text {; } A D<H C \\
\text { fornix differentiated iNPH } \\
\text { from } A D\end{array}$ \\
\hline Huang et al., 2012 & $\begin{array}{l}26 \mathrm{AD}[70.8 \pm 8.2 \text { years, } 15 \mathrm{M} .11 \mathrm{~F}] \\
11 \mathrm{aMCl}[69.1 \pm 7.3 \text { years, } 5 \mathrm{M}, 6 \mathrm{~F}] \\
24 \mathrm{HC}[69.5 \pm 7.1 \text { years, } 10 \mathrm{M}, 14 \mathrm{~F}]\end{array}$ & $\begin{array}{l}3 \mathrm{~T}, 30 \text { directions } \\
\text { 2. } \mathrm{mm} \text { slice }\end{array}$ & $\mathrm{ROI}$ & $\begin{array}{l}F A: A D<H C \\
M D \text { and } R D: A D>H C ; \text { No } \\
\text { group difference in } A x D\end{array}$ \\
\hline
\end{tabular}


Table 2 | Continued

\begin{tabular}{|c|c|c|c|c|}
\hline Authors & $\begin{array}{l}\text { Subjects [Mean age } \pm S D \text { (age range), Male, } \\
\text { Female] }\end{array}$ & Image Acquisition & Image Analysis & Fornix-related Findings \\
\hline $\begin{array}{l}\text { Metzler-Baddeley } \\
\text { et al., } 2012\end{array}$ & $\begin{array}{l}25 \mathrm{MCl}[76.8 \pm 7.3 \text { years, } 14 \mathrm{M}, 11 \mathrm{~F}] \\
20 \mathrm{HC}[74 \pm 6.5 \text { years, } 10 \mathrm{M}, 10 \mathrm{~F}]\end{array}$ & $\begin{array}{l}3 \mathrm{~T}, 30 \text { directions } \\
2.4 \mathrm{~mm} \text { slice }\end{array}$ & $\begin{array}{l}\text { Tractography } \\
\text { ROI }\end{array}$ & $\begin{array}{l}\text { No correlation between FA } \\
\text { and episodic memory; } \downarrow \text { FA } \\
\text { with age }\end{array}$ \\
\hline Mielke et al., 2012 & $23 \mathrm{aMCl}[75.6 \pm 5.5$ years, $16 \mathrm{M}, 7 \mathrm{~F}]$ & $\begin{array}{l}3 \mathrm{~T}, 32 \text { directions } \\
2.2 \mathrm{~mm} \text { slice }\end{array}$ & $\begin{array}{l}\text { ROI(body) } \\
3-, 6-, 12 \text {-month } \\
\text { and } 2.5 \text { yrs } \\
\text { follow-ups }\end{array}$ & $\begin{array}{l}\downarrow \text { FA correlated with } \downarrow \\
\text { memory (CVLT) and } \downarrow C D R \\
\uparrow M D, A x D, R D \text { correlate } \\
\text { with } \downarrow \text { memory } \\
\text { FA and MD predicted AD } \\
\text { progression } \\
\text { Longitudinally: no difference } \\
\text { in FA or diffusivities }\end{array}$ \\
\hline Douaud et al., 2013 & $\begin{array}{l}22 \mathrm{sMCl}[69 \pm 9 \text { years, } 11 \mathrm{M}, 11 \mathrm{~F}] \\
13 \mathrm{pMCl}[76 \pm 6 \text { years, 3M, 10F] }\end{array}$ & $\begin{array}{l}3 \mathrm{~T}, 30 \text { directions } \\
3 \mathrm{~mm} \text { slice }\end{array}$ & TBSS & $\begin{array}{l}\text { Volume: } \mathrm{pMCl}<\mathrm{sMCl} \\
\text { FA: } \mathrm{pMCl}<\mathrm{sMCl} \text { MD: } \\
\mathrm{pMCl}>\mathrm{sMCl} \\
\downarrow \mathrm{FA} \propto \uparrow \mathrm{MD} \propto \downarrow \text { vol }\end{array}$ \\
\hline Fletcher et al., 2013 & $\begin{array}{l}102[73 \pm 6.4 \text { years, } 20 \text { converters to } \mathrm{MCl} \text {, and } \\
82 \text { non-converters] }\end{array}$ & $\begin{array}{l}1.5 \mathrm{~T}, 6 \text { directions, } \\
1.5 \mathrm{~mm} \text { slice }\end{array}$ & $\begin{array}{l}1 \text { manual ROI } \\
\text { (body only) }\end{array}$ & $\downarrow F A$ and volume with age \\
\hline Canu et al., 2013 & $\begin{array}{l}22 \text { EOAD }[59.4 \pm 4.6(48-68) \text { years, } 11 \mathrm{M}, 11 \mathrm{~F}] \\
24 \text { Younger HC }[59.1 \pm 2.7(51-64) \text { years, } 12 \mathrm{M} \text {, } \\
12 \mathrm{~F}] \\
35 \text { LOAD }[75.4 \pm 4.6(68-84) \text { years, } 12 \mathrm{M}, 23 \mathrm{~F}] \\
16 \text { Older HC } 73.1 \pm 4.3(67-81) \text { years, } 6 \mathrm{M}, 10 \mathrm{~F}]\end{array}$ & $\begin{array}{l}3 \mathrm{~T}, 35 \text { directions } \\
2.3 \mathrm{~mm} \text { slice }\end{array}$ & $\begin{array}{l}\text { ROI } \\
\text { VBM }\end{array}$ & $\begin{array}{l}\text { FA: EOAD }<\text { Younger } H C \\
M D \text { and } R D: E O A D> \\
\text { Younger } H C\end{array}$ \\
\hline Zhuang et al., 2013 & $\begin{array}{l}27 \text { "late" aMCl }[81.0 \pm 4.6(74.0-88.8) \text { years, } \\
18 \mathrm{M}, 9 \mathrm{~F}] \\
39 \text { "early" aMCl }[74 \pm 5.3(72.9-90.7) \text { years, } \\
24 \mathrm{M}, 15 \mathrm{~F}] \\
155 \mathrm{HC}[79.1 \pm 4.4(72.5-90.5) \text { years, } 61 \mathrm{M}, 94 \mathrm{~F}]\end{array}$ & $\begin{array}{l}3 \mathrm{~T}, 32 \text { directions } \\
2.5 \mathrm{~mm} \text { slice }\end{array}$ & $\begin{array}{l}\text { TBSS } \\
\text { ROI }\end{array}$ & $\begin{array}{l}\mathrm{FA}: \text { late } \mathrm{aMCl}<\mathrm{HC} \text { (in left } \\
\text { fornix) } \\
\mathrm{AxD}, \mathrm{RD} \text { and } \mathrm{MD} \text { :late or late } \\
\mathrm{aMCl}>\mathrm{HC} \text { (entire fornix) } \\
\downarrow \mathrm{FA} \text { and } \uparrow \mathrm{MD} \propto \downarrow \text { episodic } \\
\text { memory }\end{array}$ \\
\hline
\end{tabular}

MRI, Magnetic Resonance Imaging; T, Tesla; TBSS, Tract-based spatial statistic; VBA, Voxel-based analysis; ROI, Region of Interest; FA, Fractional Anisotropy; MD, Mean Diffusivity, AxD, Axial Diffusivity; RD, Radial Diffusivity.

$E O A D$, early-onset Alzheimer's disease; $L O A D$, late-onset Alzheimer's disease; $H C$, Healthy controls; naMCl, non-amnesic; $M C l ; A D, A l z h e i m e r$ disease; iNPH, idiopathic normal pressure hydrocephalus; FAD, familial Alzheimer's disease; FADmc, familial Alzheimer's disease mutation carriers, FADnc, familial Alzheimer's disease non-carriers; $\mathrm{pMCl}$, amnestic $\mathrm{MCl}$ patients who progressed to probable $A D$ no earlier than 2 years after their baseline scan; sMCl, amnestic $\mathrm{MCl}$ patients who were clinically stable i.e., did not develop $A D$ for at least 3 years following their first evaluation.

WMS-R, Wechsler Memory Scale-Revised; CDR, Clinical Dementia Rating; RCFT, Rey Complex Fig Test; HVLT-R, Hopkins Verbal Learning Test-Revised. 
Table 3 | Forniceal macro- and micro-structure alterations in schizophrenia and psychiatric disorders.

\begin{tabular}{|c|c|c|c|c|}
\hline Authors & $\begin{array}{l}\text { Subjects [Mean age } \pm S D \text {, range, } \\
\text { (Male/Female)] }\end{array}$ & Image Acquisition & Image Analysis & Fornix-related Findings \\
\hline Chance et al., 1999 & $\begin{array}{l}29 \mathrm{SCZ}[70 \pm 13.8 \text { years, } 16 \mathrm{M}, 13 \mathrm{~F}] \\
33 \mathrm{HC}[69.45 \pm 12.7 \text { years, } 19 \mathrm{M}, 14 \mathrm{~F}]\end{array}$ & $\begin{array}{l}\text { Post mortem brain } \\
\text { Parrafin wax } \\
5 \mu \mathrm{m} \text { section }\end{array}$ & $\begin{array}{l}\text { Palmgren's silver } \\
\text { stain for nerve } \\
\text { fibers }\end{array}$ & $\begin{array}{l}\text { Fiber density: men < women } \\
\text { Fiber density in men: } \mathrm{SCZ}>\mathrm{HC} \text { in the } \\
\text { left fornix only } \\
\text { No group difference in the numbers of } \\
\text { fibers }\end{array}$ \\
\hline Davies et al., 2001 & $\begin{array}{l}17 \mathrm{SCZ}[16.9 \pm 0.4(14.83-20.5) \text { years, } \\
11 \mathrm{M}, 6 \mathrm{~F}] \\
9 \mathrm{PsyC}[16.25 \pm 0.5(12.7-17.8) \text { years, } \\
6 \mathrm{M}, 38 \mathrm{~F}] \\
8 \mathrm{HC}[16.9 \pm 0.58 \text { (14-18.3) years, } \\
4 \mathrm{M}, 4 \mathrm{~F}]\end{array}$ & $\begin{array}{l}1.5 \mathrm{~T} \\
\mathrm{MRI} \\
1.5 \mathrm{~mm} \text { slice }\end{array}$ & ROI (body) & $\begin{array}{l}\text { Area: } \mathrm{SCZ}>\mathrm{HC}(+39.69 \%) \\
\text { Area: } \mathrm{SCZ}>\mathrm{PsyC}(+26.23 \%) \\
\text { Area: } \mathrm{HC}=\mathrm{PsyC}\end{array}$ \\
\hline Zahajszky et al., 2001 & $\begin{array}{l}15 \mathrm{SCZ}[37.6 \pm 9.3(20-54) \text { years }] \\
15 \text { matched HC [37.9 } \pm 8.8(23-54) \\
\text { years] } \\
\text { Only men }\end{array}$ & $\begin{array}{l}1.5 \mathrm{~T} \\
\mathrm{MRI} \\
6 \text { directions } \\
3 \mathrm{~mm} \text { slice }\end{array}$ & $\begin{array}{l}\text { ROI } \\
\text { (body and crus) }\end{array}$ & $\begin{array}{l}\text { No difference in volume between } \\
\text { groups. } \\
\text { No association between volume and } \\
\text { illness or between volume and } \\
\text { cognitive/clinical measures. }\end{array}$ \\
\hline $\begin{array}{l}\text { Abdul-Rahman et al., } \\
2011\end{array}$ & $\begin{array}{l}33 \mathrm{SCZ}[39.4 \pm 8.82 \text { years, } 24 \mathrm{M}, 7 \mathrm{~F}] \\
31 \mathrm{HC}[35.4 \pm 8.82 \text { years, } 25 \mathrm{M}, 8 \mathrm{~F}]\end{array}$ & $\begin{array}{l}3 \mathrm{~T} \\
15 \text { directions } \\
3 \mathrm{~mm} \text { slice }\end{array}$ & $\begin{array}{l}\text { ROI } \\
\text { Tractography }\end{array}$ & $\begin{array}{l}\text { FA: } S C Z<H C \\
R D: S C Z>H C \text {, no difference in AxD } \\
\text { Specific loci of FA reduction within the } \\
\text { fornix } \\
\text { in } S C Z, \downarrow F A \alpha \uparrow \text { psychopathology }\end{array}$ \\
\hline $\begin{array}{l}\text { Fitzsimmons et al., } \\
2014\end{array}$ & $\begin{array}{l}21 \mathrm{FES}[21.71 \pm 4.86 \text { years, } 16 \mathrm{M}, 5 \mathrm{~F}] \\
22 \mathrm{HC}[21.23 \pm 3.29 \text { years, } 13 \mathrm{M}, 9 \mathrm{~F})\end{array}$ & $\begin{array}{l}3 \mathrm{~T} \\
51 \text { directions } \\
\text { Slice not reported }\end{array}$ & $\begin{array}{l}\text { Tractography } \\
\text { ROI }\end{array}$ & $\begin{array}{l}\text { FA: FES }<H C \\
M D, R D \text { and } A x D: F E S>H C \\
M D \text { (left) }<M D \text { (right) in FES only } \\
\text { No correlation between DTI metrics } \\
\text { and clinical characteristics }\end{array}$ \\
\hline Kendi et al., 2008 & $\begin{array}{l}15 \mathrm{SCZ}[14.5 \pm 2.6 \text { (8-19 years), 7M, } \\
8 \mathrm{~F})] \\
15 \mathrm{HC}[15.1 \pm 2.5 \text { (8-19 years), (8M, } \\
7 \mathrm{~F}]\end{array}$ & $\begin{array}{l}3 \mathrm{~T} \\
12 \text { directions } \\
2 \mathrm{~mm}\end{array}$ & $\mathrm{ROI}$ & $\begin{array}{l}\text { Volume: } \mathrm{SCZ}<\mathrm{HC}(-11 \%) \\
\text { No changes in FA }\end{array}$ \\
\hline Kuroki et al., 2006 & $\begin{array}{l}24 S C Z[40.3 \pm 8.5 \text { years }(24-52 \\
\text { years })] \\
31 \mathrm{HC}[40.6 \pm 8.7 \text { years }(23-54 \text { years })] \\
\text { Only men }\end{array}$ & $\begin{array}{l}1.5 \mathrm{~T} \\
6 \text { directions } \\
4 \mathrm{~mm} \text { slice }\end{array}$ & $\mathrm{ROI}$ & $\begin{array}{l}\text { FA: SCZ }<\text { HC }(-7.5 \%) \\
\text { MD: SCZ }>\text { HC }(+6.7 \%) \\
\text { Volume: SCZ }<\text { HC }(-15.5 \%) \\
\downarrow F A \alpha \uparrow \text { medication dosage } \\
\downarrow \text { cross-sectional area } \alpha \downarrow \text { global } \\
\text { attention scores } \\
\downarrow \text { cross-sectional area } \alpha \downarrow \text { hippocampal } \\
\text { volume }\end{array}$ \\
\hline
\end{tabular}


Table 3 | Continued

\begin{tabular}{|c|c|c|c|c|}
\hline Authors & $\begin{array}{l}\text { Subjects [Mean age } \pm S D \text {, range, } \\
\text { (Male/Female)] }\end{array}$ & Image Acquisition & Image Analysis & Fornix-related Findings \\
\hline Lee et al., 2013 & $\begin{array}{l}17 \mathrm{FES}[21.5 \pm 4.8 \text { (18-30 years), } \\
13 \mathrm{M}, 4 \mathrm{~F}] \\
17 \mathrm{HC}[23.1 \pm 3.5 \text { (18-30 years), 12M, } \\
5 \mathrm{~F}]\end{array}$ & $\begin{array}{l}3 \mathrm{~T} \\
51 \text { directions } \\
1.7 \mathrm{~mm}\end{array}$ & $\begin{array}{l}\text { TBSS } \\
\text { ROI }\end{array}$ & $\begin{array}{l}\text { FA: FES }<\mathrm{HC} \\
\text { In the right fornix only, } \downarrow \text { FA } \alpha \downarrow \text { reading } \\
\text { scores } \\
\text { No effect of medication on FA in FES } \\
\text { group }\end{array}$ \\
\hline Luck et al., 2010 & $\begin{array}{l}32 \text { FES }[23.6 \pm 0.7 \text { years, } 22 \mathrm{M}, 10 \mathrm{~F})] \\
25 \mathrm{HC}[24.5 \pm 0.8 \text { years, }(13 \mathrm{M}, 12 \mathrm{~F}]\end{array}$ & $\begin{array}{l}1.5 \mathrm{~T} \\
60 \text { directions } \\
4.4 \mathrm{~mm} \text { slice }\end{array}$ & Tractography & FA: FES < HC \\
\hline Nestor et al., 2007 & $\begin{array}{l}21 \mathrm{SCZ}[39.79 \pm 9.16(18-55 \text { years })] \\
24 \mathrm{HC}[40.64 \pm 9.38(18-55 \text { years })] \\
\text { Only men }\end{array}$ & $\begin{array}{l}1.5 \mathrm{~T} \\
6 \text { directions } \\
4 \mathrm{~mm} \text { slice }\end{array}$ & $\mathrm{ROI}$ & 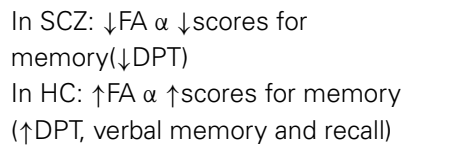 \\
\hline Takei et al., 2008 & $\begin{array}{l}31 \mathrm{SCZ}[33.8 \pm 9.0 \text { (22-55 years), } \\
12 \mathrm{M}, 19 \mathrm{~F})] \\
65 \mathrm{HC}[34.7 \pm 9.7 \text { (21-54 years), 24M, } \\
41 \mathrm{~F}]\end{array}$ & $\begin{array}{l}1.5 \mathrm{~T} \\
6 \text { directions } \\
\text { Slice not reported }\end{array}$ & $\begin{array}{l}\text { Tractography } \\
\text { ROI }\end{array}$ & 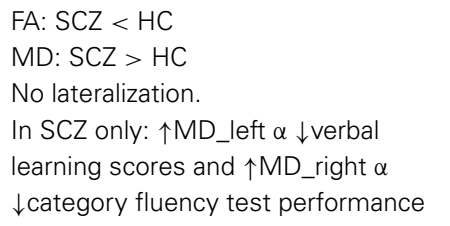 \\
\hline Smith et al., 2006 & 33 SCZ, 15 MS, Not reported & $\begin{array}{l}1.5 \mathrm{~T} \\
10 \text { directions } \\
2.5 \mathrm{~mm}\end{array}$ & TBSS & FA: SCZ $<\mathrm{HC}$ \\
\hline $\begin{array}{l}\text { Maier-Hein et al., } \\
2014\end{array}$ & $\begin{array}{l}20 \text { BPD }[16.7 \pm 1.6(14-18 \text { years })] \\
20 \text { mixed psychosis diagnoses }(\mathrm{CC}) \\
{[16.0 \pm 1.3(14-18 \text { years })]} \\
20 \mathrm{HC}[16.8 \pm 1.2(14-18 \text { years })] \\
\text { Only women }\end{array}$ & $\begin{array}{l}3 \mathrm{~T} \\
12 \text { directions } \\
2.5 \mathrm{~mm} \text { slice }\end{array}$ & $\begin{array}{l}\text { TBSS } \\
\text { ROI }\end{array}$ & $\mathrm{FA}: \mathrm{BPD}<\mathrm{HC}=\mathrm{CC}$ \\
\hline
\end{tabular}

$\alpha$ : correlate.

MRI, Magnetic Resonance Imaging; T, Tesla; TBSS, Tract-based spatial statistic; VBA, Voxel-based analysis; ROI, Region of Interest; FA, Fractional Anisotropy; MD, Mean Diffusivity, AxD, Axial Diffusivity; RD, Radial Diffusivity.

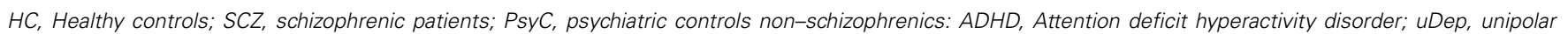
Depression, bDep, bipolar depression; BPD, bipolar disorder; FES, first episode schizophrenia.

DPT, Doors and People Test.

postmortem brain tissues (Brisch et al., 2008), and in an in vivo MRI study (Zahajszky et al., 2001). In contrast, larger fornices were found on MRI of adolescent SCZ (ages 16-17 years, both males and females) compared to healthy controls and to patients with other serious psychiatric disorders (Davies et al., 2001). These variable findings regarding the forniceal volume might have resulted from the different subject populations and the less well defined fornix structures on these earlier structural MRI studies.

Findings on the fornix measurement have been more consistent across DTI studies. Using tractography, forniceal bundle volume in SCZ adolescents and adults were smaller [-11-16\%] than in healthy controls (Kuroki et al., 2006; Kendi et al., 2008). The various DTI studies and approaches, using tractography, regions of interest (ROI) and tract-based spatial statistics (TBSS), consistently showed that FA of the fornix is lower in SCZ patient compared to healthy control. The lower than normal FA appears early at the onset of SCZ, which typically occurs just before adolescence (Davenport et al., 2010). This phenotype was reported in adolescent patients with their first episode of SCZ (Lee et al., 2009), in SCZ young adults (Luck et al., 2010; Fitzsimmons et al., 2014) and in mid-life SCZadults (Kuroki et al., 2006; Takei et al., 2008; Fitzsimmons et al., 2009; Abdul-Rahman et al., 2011), suggesting that lower than "normal" FA is a stable marker for SCZ that is retained throughout the lifespan. Lower FA in SCZ patients is frequently accompanied by either higher MD (Kuroki et al., 2006; Takei et al., 2008), RD (Abdul-Rahman et al., 2011) or both (Fitzsimmons et al., 2014). Findings on AxD are less consistent. Two studies showed no changes in AxD between SCZ patients and healthy controls (Kendi et al., 2008; Abdul-Rahman et al., 2011), whereas another study found higher AxD along with higher MD and RD in young adults with first episode schizophrenia (Fitzsimmons et al., 2014). The higher RD was suggested to be a marker of myelin disruption, higher MD a marker of 
atrophy, while $\mathrm{AxD}$ may reflect axonal disruption (Song et al., 2005). Therefore, the lower FA and higher diffusivities involving all three measures $(\mathrm{MD}, \mathrm{RD}$ and $\mathrm{AxD}$ ) possibly reflect alterations in both myelin and axons. These alterations are notable in the fornix already at illness onset, but the causative mechanism is not yet defined. Moreover, the functionality of the forniceal changes and their impacts on the limbic network is still unclear. Some studies found no association between forniceal metrics and either cognitive or clinical measures (Zahajszky et al., 2001; Fitzsimmons et al., 2009, 2014; Lee et al., 2013), while others reported that lower FA correlated with greater psychopathology (Abdul-Rahman et al., 2011) and higher medication dosage in SCZ patients (Kuroki et al., 2006). Lower FA and/or higher MD was further associated with greater episodic memory impairments (verbal and visual memory tests) in SCZ patients (Nestor et al., 2007; Takei et al., 2008; Lee et al., 2013). In healthy controls, these correlations between FA and visual and verbal memory tasks were also observed (Nestor et al., 2007; Fitzsimmons et al., 2009).

In conclusion, abnormalities in the fornix are found in SCZ patients and are most likely due to degeneration, involving both axonal injury and demyelination, of the fornix. To some extent, these microstructural abnormalities in the fornix may serve as an imaging marker for disease severity in schizophrenia, although it remains unclear whether these changes in the fornix contribute to disruption of the limbic networks and to hippocampal atrophy. In addition, DTI metrics (FA and MD) appear to be sensitive indicators of injury to the fornix and subsequent memory deficits in SCZ patients. Further investigations using these metrics, in addition to other imaging modalities (e.g., evaluating brain network connectivities), are needed to follow patients longitudinally from the prodromal period to the first episodes to understand further the evolution of the neuropathology of schizophrenia.

\section{Multiple Sclerosis and other neurodegenerative diseases (Table 4)}

Multiple Sclerosis (MS) is an autoimmune demyelinating disease that is characterized by the infiltration of macrophages and T-cells that activate glia and microglia, which lead to fulminant neuroinflammation and intense demyelination of nerve fibers (Pivneva, 2008). About half of the MS patients develop cognitive deficits and most frequently, episodic memory deficits (Brissart et al., 2011). As parts of the limbic system, both the hippocampus and the fornix were often found affected in MS patients. Compared to healthy controls, MS patients had lower magnetization transfer ratio (MTR) in the right fornix, but this abnormality in the fornix did not correlate with cognitive performance (Ranjeva et al., 2005). Using TBSS, tractography or ROI, MS patients consistently showed lower FA with higher MD and RD in the fornix than healthy controls across studies and during adulthood (Smith et al., 2006; Dineen et al., 2009, 2012; Roosendaal et al., 2009; Fink et al., 2010; Kern et al., 2012; Koenig et al., 2013; Syc et al., 2013). Findings on $\mathrm{AxD}$ in the fornix were less consistent and less systematically investigated. Forniceal AxD showed either no group differences (Dineen et al., 2012) or higher values in MS compared to healthy controls (Roosendaal et al., 2009; Syc et al., 2013). In most of these studies, MS patients with lower FA and higher diffusivity metrics in the fornix had poorer performance in verbal and visual memory or recall and greater episodic memory impairments (Brief Visual Memory Test-Revised) (Dineen et al., 2009, 2012; Koenig et al., 2013, 2014; Syc et al., 2013). Moreover, these forniceal DTI metrics correlated with Expanded Disability Status Scale (EDSS) and disease duration in these MS patients (Syc et al., 2013; Koenig et al., 2014).

Altogether, these findings showed that DTI metrics in the fornix are consistently abnormal in MS patients. Since DTI measures in the fornix can assess disease severity, they may be useful for monitoring MS disease progression. Furthermore, forniceal DTI metrics correlated with hippocampal volume in patients with MS, and DTI measures in the fornix had an even stronger association with visual and episodic memory than the hippocampal volume (Koenig et al., 2014). Therefore, similar to patients who convert from MCI to AD, longitudinal forniceal DTI measures may be useful in predicting hippocampal abnormalities and memory deficits in MS patients.

Parkinson's disease. Parkinson's disease (PD) is most commonly regarded as a movement disorder (Gelb et al., 1999), since degeneration of the nigrostriatal dopaminergic system leads to dysfunction of the motor system with the four cardinal signs of tremors, bradykinesia, rigidity and postural instability. However, dopamine also mediates attention and working memory, which are requried for most higher level cognitive function, Therefore, PD patients commonly develop dementia and cognitive deficits including deficits in executive function, attention, language and memory (Zgaljardic et al., 2003; McKinlay et al., 2010). Few studies investigated the fornix in PD patients using DTI. Similar to $\mathrm{AD}$ patients, $\mathrm{MD}$ of the fornix was higher in $\mathrm{PD}$ patients than in healthy adults (Kim et al., 2013), and higher MD correlated with worse short-term non-verbal memory (Zheng et al., 2014). However, since many dementia patients have co-occurrence of $\mathrm{AD}$ and $\mathrm{PD}$, it remains unclear whether the fornix abnormalities are related specifically to PD. Depression is also common amongst PD patients, and those with depression showed lower FA in the frontal white matter than PD patients without depression; although the fornix was not specifically evaluated in this study, and the temporal white matter showed no group difference (Matsui et al., 2007). Another DTI study found that PD patients with excessive daytime sleepiness (Epsworth Sleepiness Scale $\geq 10$ ) had significantly lower FA in their fornix compared to controls (Matsui et al., 2006). Therefore, abnormalities in the fornix appear to contribute to the co-morbid symptoms beyond the extrapyramidal system, such as memory deficits and excessive daytime sleepiness in patients with PD.

Epilepsy. Since a large number of etiologies exist for epilepsy, the fornix may or may not be affected depending on whether this major efferent white matter tract from the hippocampi is affected by the lesion or condition that caused the epilepsy. For instance, mesial temporal sclerosis (MTS) causes temporal lobe epilepsy (TLE), and is frequently accompanied by forniceal atrophy and lower FA when the fornix of these patients are compared to non-epileptic controls (Baldwin et al., 1994; Kim et al., 1995). Decreased fornix volumes and lower FA were often associated with ipsilateral hippocampal sclerosis, both quantitatively and qualitatively (Baldwin et al., 1994; Kuzniecky et al., 
Table 4 | Forniceal macro- and micro-structure alterations in multiple sclerosis and other neurodegenerative diseases.

\begin{tabular}{|c|c|c|c|c|}
\hline Authors & $\begin{array}{l}\text { Subjects [Mean age } \pm S D \text { (range), } M \\
\text { (male), } F \text { (female)] }\end{array}$ & $\begin{array}{l}\text { Image } \\
\text { Acquisition }\end{array}$ & $\begin{array}{l}\text { Image } \\
\text { Analysis }\end{array}$ & Fornix-related Findings \\
\hline \multicolumn{5}{|c|}{ MULTIPLE SCLEROSIS (MS) } \\
\hline Dineen et al., 2012 & $\begin{array}{l}34 \text { relapsing-remitting MS }[42.6(31.1-56.1) \\
\text { years, } 11 \mathrm{M}, 13 \mathrm{~F}] \\
24 \mathrm{HC}[38.7(28.3-55.3) \text { years, 9M, 15F] }\end{array}$ & $\begin{array}{l}3 \mathrm{~T} \\
15 \text { directions } \\
2.5 \mathrm{~mm} \text { slice }\end{array}$ & $\mathrm{ROI}$ & $\begin{array}{l}\text { FA: MS }<\text { HC } \\
\text { RD: MS > HC; no group difference in AxD } \\
\downarrow F A \alpha \downarrow \text { episodic memory scores (CVLT } \\
\text { and BVRT) }\end{array}$ \\
\hline Kern et al., 2012 & $\begin{array}{l}18 \mathrm{MS}[42.1 \text { (23-54.5 years), 14M, 4F] } \\
16 \mathrm{HC}[35.2 \text { (24-50.3 years), 14M, 2F] }\end{array}$ & $\begin{array}{l}3 \mathrm{~T} \\
12 \text { directions } \\
3 \mathrm{~mm} \text { slice }\end{array}$ & TBSS & $\begin{array}{l}\text { FA: } M S<H C \\
\text { In MS: } \downarrow F A \alpha \downarrow \text { verbal memory } \\
\text { performance }\end{array}$ \\
\hline Koenig et al., 2013 & $\begin{array}{l}40 \mathrm{MS}[42.55 \pm 9.1 \text { (32-52 years), 11M, } \\
29 \mathrm{~F}] \\
20 \mathrm{HC}[41.35 \pm 9.7 \text { (32-52 years), 7M, 13] }\end{array}$ & $\begin{array}{l}3 \mathrm{~T} \\
71 \text { directions } \\
1 \mathrm{~mm} \text { slice }\end{array}$ & $\mathrm{ROI}$ & $\begin{array}{l}\text { FA: } M S<H C \\
R D \text { and } M D: M S>H C \\
\text { In MS: } \uparrow R D, M D \text { and } \downarrow F A(\text { Left-fornix) } \alpha \\
\downarrow \text { episodic memory (BVMT-R scores) } \\
\text { No group difference in volume }\end{array}$ \\
\hline $\begin{array}{l}\text { Roosendaal et al., } \\
2009\end{array}$ & $\begin{array}{l}30 \mathrm{MS}[40.6 \pm 9.1,11 \mathrm{M}, 19 \mathrm{~F}] \\
31 \mathrm{HC}[40.6 \pm 9.9 \text { years, } 10 \mathrm{M}, 21 \mathrm{~F})]\end{array}$ & $\begin{array}{l}1.5 \mathrm{~T} \\
61 \text { directions } \\
3 \mathrm{~mm} \text { slice }\end{array}$ & $\begin{array}{l}\text { TBSS } \\
\text { ROI }\end{array}$ & $\begin{array}{l}\text { FA: } M S<H C \\
R D \text { and AxD: MS }>H C \\
\text { No correlation between FA and EDSS }\end{array}$ \\
\hline Syc et al., 2013 & $\begin{array}{l}64 \text { RRMS }[39 \pm 11(32-52 \text { years), 23M, 41F] } \\
24 \text { SPMS [ } 55 \pm 8 \text { (32-52 years), 7M, 17F] } \\
13 \text { PPMS [56 } \pm 7(32-52 \text { years), 7M, 6F] } \\
16 \mathrm{HC}[40 \pm 9 \text { (32-52 years), 5M, 11F] }\end{array}$ & $\begin{array}{l}3 \mathrm{~T} \\
\text { MTR } \\
1.5 \mathrm{~mm} \text { slice }\end{array}$ & $\begin{array}{l}\text { Tractography } \\
\text { ROI }\end{array}$ & $\begin{array}{l}\text { FA: MS }<H C(-19 \%) \\
M D, R D \text { and } A x D: M S>H C(+13 \%) \\
\downarrow F A \text { and } \uparrow M D, R D, A x D \alpha \uparrow E D S S \text { and } \\
\uparrow \text { disease duration } \\
\downarrow F A \text { and } \uparrow M D, R D \alpha \downarrow P A S A T-3 \text { scores } \\
\downarrow F A \text { and } \uparrow M D, R D \text { and AxD } \alpha \uparrow 9-H P T \\
\text { times }\end{array}$ \\
\hline \multicolumn{5}{|c|}{ PARKINSON'S DISEASE (PD) } \\
\hline Matsui et al., 2006 & $\begin{array}{l}11 \mathrm{PD} \text { with EDS (ESS }>10)[72.2 \pm 7.2 \\
\text { years, 8M, 3M] } \\
26 \mathrm{PD} \text { without EDS }[71.22419 .2 \text { years, 23F, } \\
3 \mathrm{M}] \\
10 \text { controls }[72.4 \pm 6.4 \text { years, } 7 \mathrm{M} / 3 \mathrm{~F}]\end{array}$ & $\begin{array}{l}1.5 \mathrm{~T} \\
6 \text { directions } \\
4 \mathrm{~mm} \text { slice }\end{array}$ & 5 manual ROls & $\begin{array}{l}\text { FA: PD with EDS < PD without EDS or } \\
\text { controls } \\
\text { FA } \alpha \text { with Epworth Sleepiness Scale (ESS) }\end{array}$ \\
\hline
\end{tabular}


Table 4 | Continued

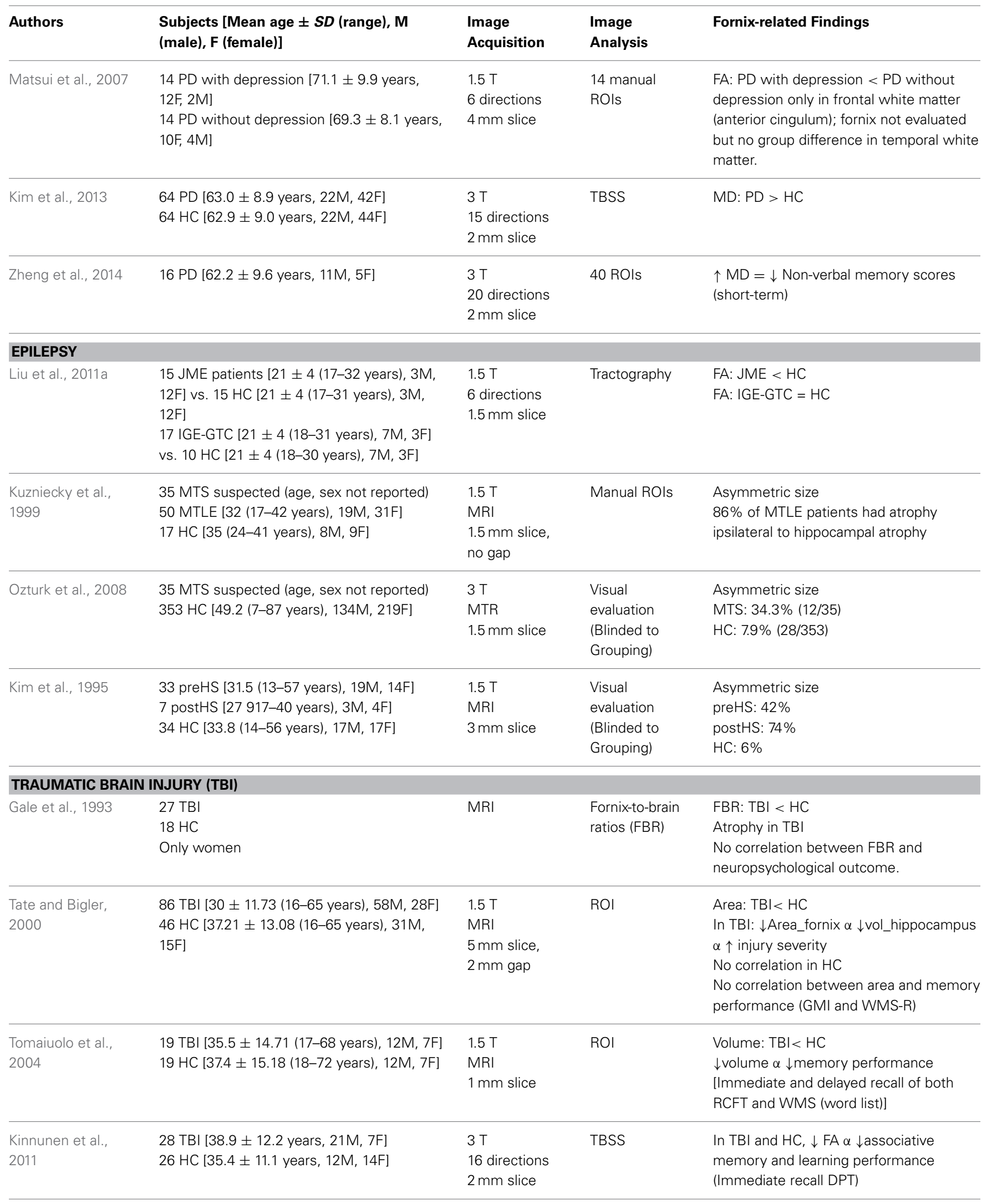


Table 4 | Continued

\begin{tabular}{|c|c|c|c|c|}
\hline Authors & $\begin{array}{l}\text { Subjects [Mean age } \pm S D \text { (range), M } \\
\text { (male), F (female)] }\end{array}$ & $\begin{array}{l}\text { Image } \\
\text { Acquisition }\end{array}$ & $\begin{array}{l}\text { Image } \\
\text { Analysis }\end{array}$ & Fornix-related Findings \\
\hline Palacios et al., 2011 & $\begin{array}{l}15 \mathrm{TBI}[23.6 \pm 4.79(18-32 \text { years), 11M, 4F }] \\
16 \mathrm{HC}[23.7 \pm 4.8 \text { (18-32 years), 9M, 7F }]\end{array}$ & $\begin{array}{l}1.5 \mathrm{~T} \\
25 \text { directions } \\
5 \mathrm{~mm} \text { slice }\end{array}$ & $\begin{array}{l}\text { TBSS } \\
\text { ROI }\end{array}$ & $\begin{array}{l}\text { FA: TBI }<\mathrm{HC} \\
\text { In TBI: } \downarrow \text { FA in fornix } \alpha \text { with worse } \\
\text { declarative memory but not with working } \\
\text { memory; } \downarrow \text { FA in SLF } \alpha \text { with working } \\
\text { memory }\end{array}$ \\
\hline
\end{tabular}

Adnan et al., $2013 \quad 29$ TBI [5 and 30 months post-injury]

$\mathrm{ROI}$

FA: TBI $<\mathrm{HC}$

\section{$\alpha$ : correlate.}

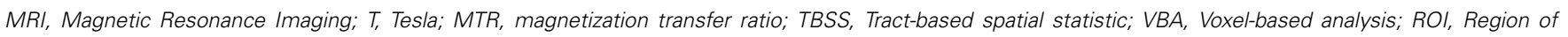
Interest; MO, mode of anisotropy; FA, fractional anisotropy; MD, Mean Diffusivity, AxD, Axial diffusivity; RD, Radial diffusivity.

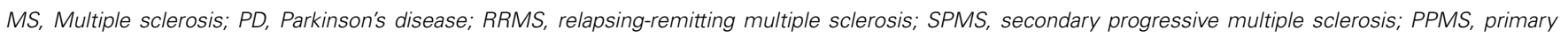

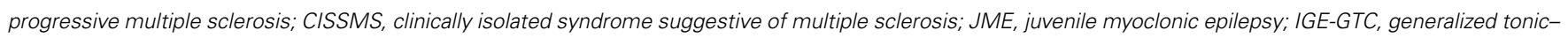

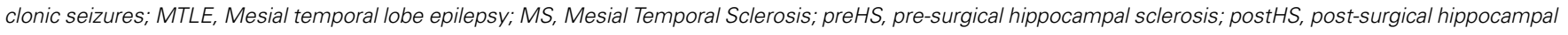
sclerosis; TBI, Traumatic brain injury.

EDSS, Expanded Disability Status Scale; 9-HPT, 9-Hole Peg Test; PASAT-3, Paced Auditory serial Addition Task-3, second version; GMI, General Memory Index score; WMS-R, Wechsler Memory Scale-Revised; RCFT, Rey Complex Fig Test; BVMT-R, Brief Visuospatial Memory Test-Revised; SDMT, Symbol Digit Modalities Test.

1999), and appear to be a good predictor of TLE with accurate lateralization. Therefore, evaluating the fornix and its asymmetry, even with visual interpretations, may be useful in support of presurgical planning (i.e., for surgical resection) for patients with medically intractable TLE. In addition, low frequency depth electrode stimulation of the fornix led to hippocampal and posterior cingulum responses, demonstrating these functional connections, and reduced interictal epileptiform discharges and seizures in patients with intractable mesial temporal lobe epilepsy, without affecting their memory (Koubeissi et al., 2013). Depth electrode stimulation of the fornix also led to either ipsilateral or contralateral hippocampal responses, which again confirmed these neural pathway connections and explained how seizure discharge might spread between homotopic mesial temporal structures without neocortical involvement (Lacuey et al., 2014).

Lastly, a recent DTI study, using tractography, found that patients with juvenile myoclonic epilepsy (JME) had lower FA in the crus of the fornix, body of the corpus callosum and many other major white matter tracts, but not in those with only generalized tonic-clonic seizures, suggesting different neuroanatomical substrates in these two different types of idiopathic generalized epilepsies (Liu et al., 2011a). Taken together, these studies demonstrate that the fornix may play a role in mediating seizure spreads across the cerebral hemispheres both in patients with temporal lobe epilepsy as well as in generalized epilepsies. However, it may also be a treatment target for deep brain stimulation or surgical approaches in these patients.

Traumatic Brain Injury (TBI) results from physical forces that damage the brain, which may cause cognitive impairments such as memory and attention deficits. TBI is also associated with atrophy of the fornix (Gale et al., 1993; Tate and Bigler, 2000; Tomaiuolo et al., 2004). The fornix is particularly susceptible to physical shearing forces (Tate and Bigler, 2000), probably due to its delicate fiber tracts that straddle both cerebral hemispheres.
The effects of TBI on the fornix volume have been examined in relation to memory. However, only one of the three studies (Tate and Bigler, 2000; Gale et al., 1993; Tomaiuolo et al., 2004) found a correlation between forniceal atrophy and memory performance (Tomaiuolo et al., 2004). However, using DTI with TBSS, white matter abnormalities were observed in several regions of the brain in TBI patients, but only lower FA in the fornix correlated with worse performance in associative memory and learning in both the TBI and healthy control groups (Kinnunen et al., 2011). In another study, patients with diffuse TBI, which leads to diffuse axonal injury, had globally decreased FA in the brain. However, regional analyses showed that lower FA in the superior longitudinal fasciculus was associated with working memory deficits, while lower forniceal FA was associated with poorer declarative memory in these TBI patients with diffuse injuries (Palacios et al., 2011). Lower forniceal FA and memory deficits were consistently found in TBI patients compared to healthy controls (Palacios et al., 2011; Adnan et al., 2013), suggesting a critical role of the fornix integrity in the development of memory impairments after TBI.

\section{DISCUSSION}

\section{LIMITATIONS AND FUTURE STUDIES}

Several factors have limited the study of the fornix. First, the anatomy of the fornix makes it difficult to evaluate the abnormalities in this brain structure. Specific regions of the fornix (i.e., column, crus or pre-commissural fornix) are even more difficult to visualize or quantify. DTI has improved the visualization of the fornix, which has led to many more studies of this structure in several neurological disorders. However, the forniceal DTI measures in the published studies are often affected by the fornix's close proximity to the ventricles, which can lead to partial volume effects from the CSF in the ventricles. While CSF suppression (using inversion recovery pulses on MRI) would suppress the signals from CSF, most of the DTI studies did not apply such CSF signal suppression during the image acquisition. Partial volume 
effect from adjacent CSF signal may generate biased (higher) diffusivity and (lower) FA values of the fornix although this structure is generally well delineated on DTI. Nevertheless, refined methods have been developed to minimize the CSF partial volume effect on DTI and obtain higher resolution images. These improved DTI acquisition methods include reducing the repetition time and using non-zero minimum diffusion weighting (Baron and Beaulieu, 2014), or increased the image resolution of DTI (Herbst et al., 2014) by combining multiplexed sensitivity encoding (Chen et al., 2013) and prospective motion correction (Zaitsev et al., 2006; Herbst et al., 2012; Gumus et al., 2014). Others have developed novel criteria for DTI metric selection (Pasternak et al., 2010) using relationships between distribution and distance of the measured diffusion quantities or the use of multi-contrast MRI (Tang et al., 2014) with an automated parcellation atlas, which may further delineate and accurately assess how the fornix might be affected in various brain disorders. Second, the various methods (e.g., manual or automated ROIs, TBSS, tractography) used to measure the diffusivities and FA in the fornix do not always yield the same results. Systematic comparisons or the use of more than one approach to measure the fornix in the same datasets could provide validation to the abnormal findings in the various brain disorders. Third, the majority of the studies reviewed utilized a cross-sectional design, longitudinal follow-up studies would minimize the potential confounding effects of inter-subject variability (e.g., due to differences in disease severity or illness duration) or premorbid group differences. Intra-subject measurements in longitudinal evaluations are more sensitive in detecting, predicting and monitoring neurodegeneration compared to cross-sectional measures. Despite these limitations, the studies reviewed consistently showed correlations between DTI metrics in the fornix and memory performance of typically aging individuals and in patients with various neurodegenerative and neuropsychiatric disorders. These findings strengthen the role of the fornix as a useful imaging marker to predict memory deficits or impairments.

\section{CONCLUSION}

The fornix is clearly a critical component of the limbic system and is closely linked to memory performance. Alterations of the fornix are related to cognitive functions in childhood and in later life. In addition, forniceal changes were found in schizophrenia and other psychiatric disorders. Therefore, the fornix appears to be more than a clinical surrogate marker of memory impairments for neurodegenerative and neuroinflammatory diseases, such as Alzheimer's disease and multiple sclerosis. Although the fornix is one of the less heritable brain structures (Jahanshad et al., 2013), few studies reported how genes might influence the typical development or aging of the fornix. Imaging genetics might be useful to further elucidate the role of the fornix in various brain disorders as well as during healthy neurodevelopment and brain aging.

\section{ACKNOWLEDGMENTS}

We thank Eric Cunningham and Kristin Lee for carefully editing this manuscript. NIH grant supports: K24 DA016170 \& G12-MD007601.

\section{REFERENCES}

Abdul-Rahman, M. F., Qiu, A., and Sim, K. (2011). Regionally specific white matter disruptions of fornix and cingulum in schizophrenia. PLOS ONE 6:e18652. doi: 10.1371/journal.pone.0018652

Adnan, A., Crawley, A., Mikulis, D., Moscovitch, M., Colella, B., and Green, R. (2013). Moderate-severe traumatic brain injury causes delayed loss of white matter integrity: evidence of fornix deterioration in the chronic stage of injury. Brain Inj. 27, 1415-1422. doi: 10.3109/02699052.2013.823659

Aggleton, J. P., Vann, S. D., Oswald, C. J., and Good, M. (2000). Identifying cortical inputs to the rat hippocampus that subserve allocentric spatial processes: a simple problem with a complex answer. Hippocampus 10, 466-474. doi: 10.1002/1098-1063(2000)10:4<466::AID-HIPO13>3. $0 . \mathrm{CO} ; 2-\mathrm{Y}$

Arnold, S. E., Franz, B. R., Gur, R. C., Gur, R. E., Shapiro, R. M., Moberg, P. J., et al. (1995). Smaller neuron size in schizophrenia in hippocampal subfields that mediate cortical-hippocampal interactions. Am. J. Psychiatry 152, 738-748.

Asato, M. R., Terwilliger, R., Woo, J., and Luna, B. (2010). White matter development in adolescence: a DTI study. Cereb. Cortex 20, 2122-2131. doi: $10.1093 /$ cercor/bhp282

Baldwin, G. N., Tsuruda, J. S., Maravilla, K. R., Hamill, G. S., and Hayes, C. E. (1994). The fornix in patients with seizures caused by unilateral hippocampal sclerosis: detection of unilateral volume loss on MR images. AJR Am. J. Roentgenol. 162, 1185-1189. doi: 10.2214/ajr.162.5.8166008

Baron, C. A., and Beaulieu, C. (2014). Acquisition strategy to reduce cerebrospinal fluid partial volume effects for improved DTI tractography. Magn. Reson. Med. doi: 10.1002/mrm.25226. [Epub ahead of print].

Bossy-Wetzel, E., Schwarzenbacher, R., and Lipton, S. A. (2004). Molecular pathways to neurodegeneration. Nat. Med. 10, S2-S9. doi: 10.1038/nm1067

Brisch, R., Bernstein, H. G., Stauch, R., Dobrowolny, H., Krell, D., Truebner, K.,et al. (2008). The volumes of the fornix in schizophrenia and affective disorders: a post-mortem study. Psychiatry Res. 164, 265-273. doi: 10.1016/j.pscychresns.2007.12.007

Brissart, H., Daniel, F., Morele, E., Leroy, M., Debouverie, M., and Defer, G. L. (2011). [Cognitive rehabilitation in multiple sclerosis: a review of the literature]. Rev. Neurol. (Paris) 167, 280-290. doi: 10.1016/j.neurol.2010.07.039

Broca, P. P. (1890). "Anatomie comparée des circonvolutions cérébrales," in Extrait de la "Revue d'Anthropologie," ed Masson (Paris: Elsevier-France), Sér.2,. T. 1, 385-498.

Burzynska, A. Z., Preuschhof, C., Backman, L., Nyberg, L., Li, S. C., Lindenberger, U., et al. (2010). Age-related differences in white matter microstructure: region-specific patterns of diffusivity. Neuroimage 49, 2104-2112. doi: 10.1016/j.neuroimage.2009.09.041

Callen, D. J., Black, S. E., Gao, F., Caldwell, C. B., and Szalai, J. P. (2001). Beyond the hippocampus: MRI volumetry confirms widespread limbic atrophy in AD. Neurology 57, 1669-1674. doi: 10.1212/WNL.57.9.1669

Canu, E., Agosta, F., Spinelli, E. G., Magnani, G., Marcone, A., Scola, E., et al. (2013). White matter microstructural damage in Alzheimer's disease at different ages of onset. Neurobiol. Aging 34, 2331-2340. doi: 10.1016/j.neurobiolaging.2013.03.026

Chance, S. A., Esiri, M. M., and Crow, T. J. (2005). Macroscopic brain asymmetry is changed along the antero-posterior axis in schizophrenia. Schizophr. Res. 74, 163-170. doi: 10.1016/j.schres.2004.09.001

Chance, S. A., Highley, J. R., Esiri, M. M., and Crow, T. J. (1999). Fiber content of the fornix in schizophrenia: lack of evidence for a primary limbic encephalopathy. Am. J. Psychiatry 156, 1720-1724.

Chang, L., Friedman, J., Ernst, T., Zhong, K., Tsopelas, N. D., and Davis, K. (2007). Brain metabolite abnormalities in the white matter of elderly schizophrenic subjects: implication for glial dysfunction. Biol. Psychiatry 62, 1396-1404. doi: 10.1016/j.biopsych.2007.05.025

Chen, N. K., Guidon, A., Chang, H. C., and Song, A. W. (2013). A robust multi-shot scan strategy for high-resolution diffusion weighted MRI enabled by multiplexed sensitivity-encoding (MUSE). Neuroimage 72, 41-7. doi: 10.1016/j.neuroimage.2013.01.038

Copenhaver, B. R., Rabin, L. A., Saykin, A. J., Roth, R. M., Wishart, H. A., Flashman, L. A., et al. (2006). The fornix and mammillary bodies in older adults with Alzheimer's disease, mild cognitive impairment, and cognitive complaints: a volumetric MRI study. Psychiatry Res. 147, 93-103. doi: 10.1016/j.pscychresns.2006.01.015 
Crow, T. J., Colter, N., Frith, C. D., Johnstone, E. C., and Owens, D. G. (1989). Developmental arrest of cerebral asymmetries in early onset schizophrenia. Psychiatry Res. 29, 247-253.

Cui, Y., Sachdev, P. S., Lipnicki, D. M., Jin, J. S., Luo, S., Zhu, W., et al. (2012). Predicting the development of mild cognitive impairment: a new use of pattern recognition. Neuroimage 60, 894-901. doi: 10.1016/j.neuroimage.2012. 01.084

Davenport, N. D., Karatekin, C., White, T., and Lim, K. O. (2010). Differential fractional anisotropy abnormalities in adolescents with ADHD or schizophrenia. Psychiatry Res. 181, 193-198. doi: 10.1016/j.pscychresns.2009.10.012

Davies, D. C., Wardell, A. M., Woolsey, R., and James, A. C. (2001). Enlargement of the fornix in early-onset schizophrenia: a quantitative MRI study. Neurosci. Lett. 301, 163-166. doi: 10.1016/S0304-3940(01)01637-8

DeLisi, L. E., Sakuma, M., Kushner, M., Finer, D. L., Hoff, A. L., and Crow, T. J. (1997). Anomalous cerebral asymmetry and language processing in schizophrenia. Schizophr. Bull. 23, 255-271.

Dineen, R. A., Bradshaw, C. M., Constantinescu, C. S., and Auer, D. P. (2012). Extra-hippocampal subcortical limbic involvement predicts episodic recall performance in multiple sclerosis. PLoS ONE 7:e44942. doi: 10.1371/journal.pone.0044942

Dineen, R. A., Vilisaar, J., Hlinka, J., Bradshaw, C. M., Morgan, P. S., Constantinescu, C. S., et al. (2009). Disconnection as a mechanism for cognitive dysfunction in multiple sclerosis. Brain 132(Pt 1), 239-249. doi: 10.1093/brain/awn275

Douaud, G., Menke, R. A., Gass, A., Monsch, A. U., Rao, A., Whitcher, B., et al. (2013). Brain microstructure reveals early abnormalities more than two years prior to clinical progression from mild cognitive impairment to Alzheimer's disease. J. Neurosci. 33, 2147-2155. doi: 10.1523/JNEUROSCI.4437-12.2013

Douet, V., Chang, L., Pritchett, A., Lee, K., Keating, B., Bartsch, H., et al. (2014). Schizophrenia-risk variant rs6994992 in the neuregulin-1 gene on brain developmental trajectories in typically-developing children. Transl. Psychiatry doi: 10.1038/tp.2014.41

Dubois, J., Dehaene-Lambertz, G., Soares, C., Cointepas, Y., Le Bihan, D., and Hertz-Pannier, L. (2008). Microstructural correlates of infant functional development: example of the visual pathways. J. Neurosci. 28, 1943-1948. doi: 10.1523/JNEUROSCI.5145-07.2008

Fink, F., Eling, P., Rischkau, E., Beyer, N., Tomandl, B., Klein, J., et al. (2010). The association between California verbal learning test performance and fibre impairment in multiple sclerosis: evidence from diffusion tensor imaging. Mult. Scler. 16, 332-341. doi: 10.1177/1352458509356367

Fitzsimmons, J., Hamoda, H. M., Swisher, T., Terry, D., Rosenberger, G., Seidman, L. J., et al. (2014). Diffusion tensor imaging study of the fornix in first episode schizophrenia and in healthy controls. Schizophr. Res. 156, 157-160. doi: 10.1016/j.schres.2014.04.022

Fitzsimmons, J., Kubicki, M., Smith, K., Bushell, G., Estepar, R. S., Westin, C. F., et al. (2009). Diffusion tractography of the fornix in schizophrenia. Schizophr. Res. 107, 39-46. doi: 10.1016/j.schres.2008.10.022

Fletcher, E., Raman, M., Huebner, P., Liu, A., Mungas, D., Carmichael, O., et al. (2013). Loss of fornix white matter volume as a predictor of cognitive impairment in cognitively normal elderly individuals. JAMA Neurol. 70, 1389-1395. doi: 10.1001/jamaneurol.2013.3263

Gaffan, E. A., Gaffan, D., and Hodges, J. R. (1991). Amnesia following damage to the left fornix and to other sites. A comparative study. Brain 114(Pt 3), 1297-1313.

Gale, S. D., Burr, R. B., Bigler, E. D., and Blatter., D. (1993). Fornix degeneration and memory in traumatic brain injury. Brain Res. Bull. 32, 345-349.

Garcia-Bengochea, F., and Friedman, W. A. (1987). Persistent memory loss following section of the anterior fornix in humans. A historical review. Surg. Neurol. $27,361-364$

Gelb, D. J., Oliver, E., and Gilman, S. (1999). Diagnostic criteria for Parkinson disease. Arch. Neurol. 56, 33-39.

Giorgio, A., Santelli, L., Tomassini, V., Bosnell, R., Smith, S., De Stefano, N., et al. (2010). Age-related changes in grey and white matter structure throughout adulthood. Neuroimage 51, 943-951. doi: 10.1016/j.neuroimage.2010. 03.004

Gumus, K., Keating, B., Poser, B. A., Armstrong, B., Chang, L., Maclaren, J., et al. (2014). Prevention of motion-induced signal loss in diffusion-weighted echoplanar imaging by dynamic restoration of gradient moments. Magn. Reson. Med. 71, 2006-2013. doi: 10.1002/mrm.24857
Hattori, T., Sato, R., Aoki, S., Yuasa, T., and Mizusawa, H. (2012). Different patterns of fornix damage in idiopathic normal pressure hydrocephalus and Alzheimer disease. AJNR Am. J. Neuroradiol. 33, 274-279. doi: 10.3174/ajnr. A2780

Heckers, S., Heinsen, H., Geiger, B., and Beckmann, H. (1991). Hippocampal neuron number in schizophrenia. A stereological study. Arch. Gen. Psychiatry 48, 1002-1008.

Herbst, M., Maclaren, J., Weigel, M., Korvink, J., Hennig, J., and Zaitsev, M. (2012). Prospective motion correction with continuous gradient updates in diffusion weighted imaging. Magn. Reson. Med. 67, 326-338. doi: 10.1002/mrm. 23230

Herbst, M., Zahneisen, B., Knowes, B., Zaitsev, M., and Ernst, T. (2014). Prospective motion correction of segmented diffusion weighted EPI. Mag. Reson. Med. doi: 10.1002/mrm.25547. [Epub ahead of print].

Hermoye, L., Saint-Martin, C., Cosnard, G., Lee, S. K., Kim, J., Nassogne, M. C., et al. (2006). Pediatric diffusion tensor imaging: normal database and observation of the white matter maturation in early childhood. Neuroimage 29, 493-504. doi: 10.1016/j.neuroimage.2005.08.017

Hori, A. (1995). Unilateral volume loss of the fornix in patients with seizures caused by ipsilateral hippocampal sclerosis. AJR Am. J. Roentgenol. 164, 1304. doi: 10.2214/ajr.164.5.7717266

Huang, H., Fan, X., Weiner, M., Martin-Cook, K., Xiao, G., Davis, J., et al. (2012). Distinctive disruption patterns of white matter tracts in Alzheimer's disease with full diffusion tensor characterization. Neurobiol. Aging 33, 2029-2045. doi: 10.1016/j.neurobiolaging.2011.06.027

Huang, H., Xue, R., Zhang, J., Ren, T., Richards, L. J., Yarowsky, P., et al. (2009). Anatomical characterization of human fetal brain development with diffusion tensor magnetic resonance imaging. J. Neurosci. 29, 4263-4273. doi: 10.1523/JNEUROSCI.2769-08.2009

Huang, H., Zhang, J., Wakana, S., Zhang, W., Ren, T., Richards, L. J., et al. (2006). White and gray matter development in human fetal, newborn and pediatric brains. Neuroimage 33, 27-38. doi: 10.1016/j.neuroimage.2006.06.009

Jahanshad, N., Kochunov, P. V., Sprooten, E., Mandl, R. C., Nichols, T. E., Almasy, L., et al. (2013). Multi-site genetic analysis of diffusion images and voxelwise heritability analysis: a pilot project of the ENIGMA-DTI working group. Neuroimage 81, 455-469. doi: 10.1016/j.neuroimage.2013.04.061

Jang, S. H., Cho, S. H., and Chang, M. C. (2011). Age-related degeneration of the fornix in the human brain: a diffusion tensor imaging study. Int. J. Neurosci. 121, 94-100. doi: 10.3109/00207454.2010.531894

Kantarci, K., Senjem, M. L., Avula, R., Zhang, B., Samikoglu, A. R., Weigand, S. D. et al. (2011). Diffusion tensor imaging and cognitive function in older adults with no dementia. Neurology 77, 26-34. doi: 10.1212/WNL.0b013e31822313dc

Kasai, K., Shenton, M. E., Salisbury, D. F., Hirayasu, Y., Lee, C. U., Ciszewski, A. A., et al. (2003). Progressive decrease of left superior temporal gyrus gray matter volume in patients with first-episode schizophrenia. Am. J. Psychiatry 160 156-164. doi: 10.1176/appi.ajp.160.1.156

Kendi, M., Kendi, A. T., Lehericy, S., Ducros, M., Lim, K. O., Ugurbil, K., et al. (2008). Structural and diffusion tensor imaging of the fornix in childhoodand adolescent-onset schizophrenia. J. Am. Acad. Child Adolesc. Psychiatry 47, 826-832. doi: 10.1097/CHI.Ob013e318172ef36

Kern, K. C., Ekstrom, A. D., Suthana, N. A., Giesser, B. S., Montag, M. Arshanapalli, A., et al. (2012). Fornix damage limits verbal memory functional compensation in multiple sclerosis. Neuroimage 59, 2932-2940. doi: 10.1016/j.neuroimage.2011.09.071

Kim, H. J., Kim, S. J., Kim, H. S., Choi, C. G., Kim, N., Han, S., et al. (2013). Alterations of mean diffusivity in brain white matter and deep gray matter in Parkinson's disease. Neurosci. Lett. 550, 64-68. doi: 10.1016/j.neulet.2013.06.050

Kim, J. H., Tien, R. D., Felsberg, G. J., Osumi, A. K., and Lee, N. (1995). Clinical significance of asymmetry of the fornix and mamillary body on MR in hippocampal sclerosis. AJNR Am. J. Neuroradiol. 16, 509-515.

King, E. C., Pattwell, S. S., Sun, A., Glatt, C. E., and Lee, F. S. (2013). Nonlinear developmental trajectory of fear learning and memory. Ann. N.Y. Acad. Sci. 1304, 62-69. doi: 10.1111/nyas. 12280

Kinnunen, K. M., Greenwood, R., Powell, J. H., Leech, R., Hawkins, P. C., Bonnelle, V., et al. (2011). White matter damage and cognitive impairment after traumatic brain injury. Brain 134(Pt 2), 449-463. doi: 10.1093/brain/awq347

Kochunov, P., and Hong, L. E. (2014). Neurodevelopmental and neurodegenerative models of schizophrenia: white matter at the center stage. Schizophr. Bull. 40, 721-728. doi: $10.1093 / \mathrm{schbul} / \mathrm{sbu} 070$ 
Koenig, K. A., Lowe, M. J., Lin, J., Sakaie, K. E., Stone, L., Bermel, R. A., et al. (2013). Sex differences in resting-state functional connectivity in multiple sclerosis. AJNR Am. J. Neuroradiol. 34, 2304-2311. doi: 10.3174/ajnr. A3630

Koenig, K. A., Sakaie, K. E., Lowe, M. J., Lin, J., Stone, L., Bermel, R. A., et al. (2014). Hippocampal volume is related to cognitive decline and fornicial diffusion measures in multiple sclerosis. Magn. Reson. Imaging 32, 354-358. doi: 10.1016/j.mri.2013.12.012

Koubeissi, M. Z., Kahriman, E., Syed, T. U., Miller, J., and Durand, D. M. (2013). Low-frequency electrical stimulation of a fiber tract in temporal lobe epilepsy. Ann. Neurol. 74, 223-231. doi: 10.1002/ana.23915

Kuroki, N., Kubicki, M., Nestor, P. G., Salisbury, D. F., Park, H. J., Levitt, J. J., et al. (2006). Fornix integrity and hippocampal volume in male schizophrenic patients. Biol. Psychiatry 60, 22-31. doi: 10.1016/j.biopsych.2005. 09.021

Kuzniecky, R., Bilir, E., Gilliam, F., Faught, E., Martin, R., and Hugg, J. (1999). Quantitative MRI in temporal lobe epilepsy: evidence for fornix atrophy. Neurology 53, 496-501.

Lacuey, N., Zonjy, B., Kahriman, E. S., Kaffashi, F., Miller, J., and Luders, H. O. (2014). Functional connectivity between right and left mesial temporal structures. Brain Struct. Funct. doi: 10.1007/s00429-014-0810-0. [Epub ahead of print].

Lebel, C., Gee, M., Camicioli, R., Wieler, M., Martin, W., and Beaulieu, C. (2012). Diffusion tensor imaging of white matter tract evolution over the lifespan. Neuroimage 60, 340-352. doi: 10.1016/j.neuroimage.2011.11.094

Lee, C. E., Danielian, L. E., Thomasson, D., and Baker, E. H. (2009). Normal regional fractional anisotropy and apparent diffusion coefficient of the brain measured on a 3 T MR scanner. Neuroradiology 51, 3-9. doi: 10.1007/s00234008-0441-3

Lee, S. H., Kubicki, M., Asami, T., Seidman, L. J., Goldstein, J. M., MesholamGately, R. I., et al. (2013). Extensive white matter abnormalities in patients with first-episode schizophrenia: a diffusion tensor iimaging (DTI) study. Schizophr. Res. 143, 231-238. doi: 10.1016/j.schres.2012.11.029

Liu, M., Concha, L., Beaulieu, C., and Gross, D. W. (2011a). Distinct white matter abnormalities in different idiopathic generalized epilepsy syndromes. Epilepsia 52, 2267-2275. doi: 10.1111/j.1528-1167.2011.03313.x

Liu, Y., Spulber, G., Lehtimäki, K. K., Könönen, M., Hallikainen, I., Gröhn, H., et al. (2011b). Diffusion tensor imaging and tract-based spatial statistics in Alzheimer's disease and mild cognitive impairment. Neurobiol. Aging 32, 1558-1571. doi: 10.1016/j.neurobiolaging.2009.10.006

Luck, D., Malla, A. K., Joober, R., and Lepage, M. (2010). Disrupted integrity of the fornix in first-episode schizophrenia. Schizophr. Res. 119, 61-64. doi: 10.1016/j.schres.2010.03.027

Maier-Hein, K. H., Brunner, R., Lutz, K., Henze, R., Parzer, P., Feigl, N., et al. (2014). Disorder-specific white matter alterations in adolescent borderline personality disorder. [Research Support, Non-U.S. Gov't]. Biol. Psychiatry 75, 81-88. doi: 10.1016/j.biopsych.2013.03.031

Matsui, H., Nishinaka, K., Oda, M., Niikawa, H., Komatsu, K., Kubori, T., et al. (2006). Disruptions of the fornix fiber in Parkinsonian patients with excessive daytime sleepiness. Parkinsonism Relat. Disord. 12, 319-322. doi: 10.1016/j.parkreldis.2006.01.007

Matsui, H., Nishinaka, K., Oda, M., Niikawa, H., Komatsu, K., Kubori, T., et al. (2007). Depression in Parkinson's disease. Diffusion tensor imaging study. J. Neurol. 254, 1170-1173. doi: 10.1007/s00415-006-0236-6

McDonald, B., Highley, J. R., Walker, M. A., Herron, B. M., Cooper, S. J., Esiri, M. M., et al. (2000). Anomalous asymmetry of fusiform and parahippocampal gyrus gray matter in schizophrenia: a postmortem study. [Comparative Study Research Support, Non-U.S. Gov't]. Am. J. Psychiatry 157, 40-47. doi: 10.1176/ajp.157.1.40

McKinlay, A., Grace, R. C., Dalrymple-Alford, J. C., and Roger, D. (2010) Characteristics of executive function impairment in Parkinson's disease patients without dementia. J. Int. Neuropsychol. Soc. 16, 268-277. doi: $10.1017 /$ S1355617709991299

Metzler-Baddeley, C., Hunt, S., Jones, D. K., Leemans, A., Aggleton, J. P., and O'Sullivan, M. J. (2012). Temporal association tracts and the breakdown of episodic memory in mild cognitive impairment. Neurology 79, 2233-2240. doi: 10.1212/WNL.0b013e31827689e8

Metzler-Baddeley, C., Jones, D. K., Belaroussi, B., Aggleton, J. P., and O’Sullivan, M. J. (2011). Frontotemporal connections in episodic memory and aging: a diffusion MRI tractography study. J. Neurosci. 31, 13236-13245. doi: 10.1523/JNEUROSCI.2317-11.2011

Michielse, S., Coupland, N., Camicioli, R., Carter, R., Seres, P., Sabino, J., et al. (2010). Selective effects of aging on brain white matter microstructure: a diffusion tensor imaging tractography study. Neuroimage 52, 1190-1201. doi: 10.1016/j.neuroimage.2010.05.019

Mielke, M. M., Kozauer, N. A., Chan, K. C., George, M., Toroney, J., Zerrate, M., et al. (2009). Regionally-specific diffusion tensor imaging in mild cognitive impairment and Alzheimer's disease. Neuroimage 46, 47-55. doi: 10.1016/j.neuroimage.2009.01.054

Mielke, M. M., Okonkwo, O. C., Oishi, K., Mori, S., Tighe, S., Miller, M. I., et al. (2012). Fornix integrity and hippocampal volume predict memory decline and progression to Alzheimer's disease. Alzheimers Dement. 8, 105-113. doi: 10.1016/j.jalz.2011.05.2416

Mielke, M. M., Vemuri, P., and Rocca, W. A. (2014). Clinical epidemiology of Alzheimer's disease: assessing sex and gender differences. Clin. Epidemiol. 6 , 37-48. doi: 10.2147/CLEP.S37929

Mitchell, R. L., and Crow, T. J. (2005). Right hemisphere language functions and schizophrenia: the forgotten hemisphere? Brain 128(Pt 5), 963-978. doi: 10.1093/brain/awh466

Mitelman, S. A., Shihabuddin, L., Brickman, A. M., and Buchsbaum, M. S. (2005). Cortical intercorrelations of temporal area volumes in schizophrenia. Schizophr. Res. 76, 207-229. doi: 10.1016/j.schres.2005.01.010

Nestor, P. G., Kubicki, M., Kuroki, N., Gurrera, R. J., Niznikiewicz, M., Shenton, M. E., et al. (2007). Episodic memory and neuroimaging of hippocampus and fornix in chronic schizophrenia. Psychiatry Res. 155, 21-28. doi: 10.1016/j.pscychresns.2006.12.020

Nolte, J. (2009). The Human Brain: An Introduction Ot Its Functional Anatomy. Philadelphia, PA: Mosby Elsevier.

Nowrangi, M. A., Lyketsos, C. G., Leoutsakos, J. M., Oishi, K., Albert, M., Mori, S., et al. (2013). Longitudinal, region-specific course of diffusion tensor imaging measures in mild cognitive impairment and Alzheimer's disease. Alzheimers Dement. 9, 519-528. doi: 10.1016/j.jalz.2012.05.2186

Oishi, K., Mielke, M. M., Albert, M., Lyketsos, C. G., and Mori, S. (2012) The fornix sign: a potential sign for Alzheimer's disease based on diffusion tensor imaging. J. Neuroimaging 22, 365-374. doi: 10.1111/j.1552-6569.2011. 00633.x

Ozturk, A., Yousem, D. M., Mahmood, A., and El Sayed, S. (2008). Prevalence of asymmetry of mamillary body and fornix size on MR imaging. AJNR Am. J. Neuroradiol. 29, 384-387. doi: 10.3174/ajnr.A0801

Pagani, E., Agosta, F., Rocca, M. A., Caputo, D., and Filippi, M. (2008). Voxel-based analysis derived from fractional anisotropy images of white matter volume changes with aging. Neuroimage 41, 657-667. doi: 10.1016/j.neuroimage.2008.03.021

Palacios, E. M., Fernandez-Espejo, D., Junque, C., Sanchez-Carrion, R., Roig, T., Tormos, J. M., et al. (2011). Diffusion tensor imaging differences relate to memory deficits in diffuse traumatic brain injury. BMC Neurol. 11:24. doi: 10.1186/1471-2377-11-24

Papez, J. W. (1937). A proposed mechanism of emotion. 1937. J. Neuropsychiatry Clin. Neurosci. 7, 103-112.

Pasternak, O., Sochen, N., and Basser, P. J. (2010). The effect of metric selection on the analysis of diffusion tensor MRI data. Neuroimage 49, 2190-2204. doi: 10.1016/j.neuroimage.2009.10.071

Pelletier, A., Periot, O., Dilharreguy, B., Hiba, B., Bordessoules, M., Peres, K., et al. (2013). Structural hippocampal network alterations during healthy aging: a multi-modal MRI study. Front. Aging Neurosci. 5:84. doi: 10.3389/fnagi.2013.00084

Penfield, W., and Milner, B. (1958). Memory deficit produced by bilateral lesions in the hippocampal zone. AMA Arch. Neurol. Psychiatry 79, 475-497.

Peper, J. S., Brouwer, R. M., Schnack, H. G., van Baal, G. C., van Leeuwen, M., van den Berg, S. M., et al. (2008). Cerebral white matter in early puberty is associated with luteinizing hormone concentrations. Psychoneuroendocrinology 33, 909-915. doi: 10.1016/j.psyneuen.2008.03.017

Peper, J. S., Brouwer, R. M., Schnack, H. G., van Baal, G. C., van Leeuwen, M., van den Berg, S. M., et al. (2009). Sex steroids and brain structure in pubertal boys and girls. Psychoneuroendocrinology 34, 332-342. doi: 10.1016/j.psyneuen.2008.09.012

Petersen, R. C. (2004). Mild cognitive impairment as a diagnostic entity. J. Intern. Med. 256, 183-194. doi: 10.1111/j.1365-2796.2004.01388.x 
Petersen, R. C., Doody, R., Kurz, A., Mohs, R. C., Morris, J. C., Rabins, P. V., et al. (2001). Current concepts in mild cognitive impairment. Arch. Neurol. 58, 1985-1992. doi: 10.1001/archneur.58.12.1985

Pihlajamaki, M., Jauhiainen, A. M., and Soininen, H. (2009). Structural and functional MRI in mild cognitive impairment. Curr. Alzheimer Res. 6, 179-185. doi: $10.2174 / 156720509787602898$

Pivneva, T. A. (2008). Microglia in normal condition and pathology. Fiziol. Zh. 54, 81-89.

Rados, M., Judas, M., and Kostovic, I. (2006). In vitro MRI of brain development. Eur. J. Radiol. 57, 187-198. doi: 10.1016/j.ejrad.2005.11.019

Rajmohan, V., and Mohandas, E. (2007). The limbic system. Indian J. Psychiatry, 49, 132-139. doi: 10.4103/0019-5545.33264

Ranjeva, J. P., Audoin, B., Au Duong, M. V., Ibarrola, D., Confort-Gouny, S., Malikova, I., et al. (2005). Local tissue damage assessed with statistical mapping analysis of brain magnetization transfer ratio: relationship with functional status of patients in the earliest stage of multiple sclerosis. AJNR Am. J. Neuroradiol. 26, 119-127.

Rapoport, J. L., Giedd, J. N., and Gogtay, N. (2012). Neurodevelopmental model of schizophrenia: update 2012. Mol. Psychiatry 17, 1228-1238. doi: $10.1038 / \mathrm{mp} .2012 .23$

Ringman, J. M., O’Neill, J., Geschwind, D., Medina, L., Apostolova, L. G., Rodriguez, Y., et al. (2007). Diffusion tensor imaging in preclinical and presymptomatic carriers of familial Alzheimer's disease mutations. Brain $130(\mathrm{Pt}$ 7), 1767-1776. doi: 10.1093/brain/awm102

Roosendaal, S. D., Geurts, J. J., Vrenken, H., Hulst, H. E., Cover, K. S., Castelijns, J. A., et al. (2009). Regional DTI differences in multiple sclerosis patients. Neuroimage 44, 1397-1403. doi: 10.1016/j.neuroimage.2008.10.026

Rudebeck, S. R., Scholz, J., Millington, R., Rohenkohl, G., Johansen-Berg, H., and Lee, A. C. (2009). Fornix microstructure correlates with recollection but not familiarity memory. J. Neurosci. 29, 14987-14992. doi: 10.1523/JNEUROSCI.4707-09.2009

Sala, S., Agosta, F., Pagani, E., Copetti, M., Comi, G., and Filippi, M. (2012). Microstructural changes and atrophy in brain white matter tracts with aging. Neurobiol. Aging 33, 488-498. doi: 10.1016/j.neurobiolaging.2010.04.027

Samson, R. D., and Barnes, C. A. (2013). Impact of aging brain circuits on cognition. Eur. J. Neurosci. 37, 1903-1915. doi: 10.1111/ejn.12183

Sasson, E., Doniger, G. M., Pasternak, O., Tarrasch, R., and Assaf, Y. (2013). White matter correlates of cognitive domains in normal aging with diffusion tensor imaging. Front. Neurosci. 7:32. doi: 10.3389/fnins.2013.00032

Schaefer, J., Giangrande, E., Weinberger, D. R., and Dickinson, D. (2013). The global cognitive impairment in schizophrenia: consistent over decades and around the world. Schizophr. Res. 150, 42-50. doi: 10.1016/j.schres.2013.07.009

Schmithorst, V. J., Holland, S. K., and Dardzinski, B. J. (2008). Developmental differences in white matter architecture between boys and girls. Hum. Brain Mapp. 29, 696-710. doi: 10.1002/hbm.20431

Sexton, C. E., Kalu, U. G., Filippini, N., Mackay, C. E., and Ebmeier, K. P. (2011). A meta-analysis of diffusion tensor imaging in mild cognitive impairment and Alzheimer's disease. Neurobiol. Aging 32, 2322. doi: 10.1016/j.neurobiolaging.2010.05.019

Sexton, C. E., Mackay, C. E., Lonie, J. A., Bastin, M. E., Terriére, E., O’Carroll, R. E., et al. (2010). MRI correlates of episodic memory in Alzheimer's disease, mild cognitive impairment, and healthy aging. [Research Support, Non-U.S. Gov't]. Psychiatry Res. 184, 57-62. doi: 10.1016/j.pscychresns.2010.07.005

Simmonds, D. J., Hallquist, M. N., Asato, M., and Luna, B. (2014). Developmental stages and sex differences of white matter and behavioral development through adolescence: a longitudinal diffusion tensor imaging (DTI) study. Neuroimage 92, 356-368. doi: 10.1016/j.neuroimage.2013.12.044

Smith, S. M., Jenkinson, M., Johansen-Berg, H., Rueckert, D., Nichols, T. E., Mackay, C. E., et al. (2006). Tract-based spatial statistics: voxelwise analysis of multi-subject diffusion data. [Research Support, Non-U.S. Gov't]. Neuroimage 31, 1487-1505. doi: 10.1016/j.neuroimage.2006.02.024

Song, S. K., Sun, S. W., Ju, W. K., Lin, S. J., Cross, A. H., and Neufeld, A. H. (2003). Diffusion tensor imaging detects and differentiates axon and myelin degeneration in mouse optic nerve after retinal ischemia. Neuroimage 20, 1714-1722. doi: 10.1016/j.neuroimage.2003.07.005

Song, S. K., Sun, S. W., Ramsbottom, M. J., Chang, C., Russell, J., and Cross, A. H. (2002). Dysmyelination revealed through MRI as increased radial (but unchanged axial) diffusion of water. Neuroimage 17, 1429-1436. doi: 10.1006/nimg.2002.1267
Song, S. K., Yoshino, J., Le, T. Q., Lin, S. J., Sun, S. W., Cross, A. H., et al. (2005). Demyelination increases radial diffusivity in corpus callosum of mouse brain. Neuroimage 26, 132-40. doi: 10.1016/j.neuroimage.2005.01.028

Squire, L. R., and Zola-Morgan, S. (1991). The medial temporal lobe memory system. Science 253, 1380-1386.

Stadlbauer, A., Salomonowitz, E., Strunk, G., Hammen, T., and Ganslandt, O. (2008). Quantitative diffusion tensor fiber tracking of age-related changes in the limbic system. Eur. Radiol. 18, 130-137. doi: 10.1007/s00330-007-0733-8

Stricker, N. H., Schweinsburg, B. C., Delano-Wood, L., Wierenga, C. E., Bangen, K. J., Haaland, K. Y., et al. (2009). Decreased white matter integrity in late-myelinating fiber pathways in Alzheimer's disease supports retrogenesis. Neuroimage 45, 10-16. doi: 10.1016/j.neuroimage.2008.11.027

Sullivan, E. V., Rohlfing, T., and Pfefferbaum, A. (2010). Quantitative fiber tracking of lateral and interhemispheric white matter systems in normal aging: relations to timed performance. Neurobiol. Aging 31, 464-481. doi: 10.1016/j.neurobiolaging.2008.04.007

Syc, S. B., Harrison, D. M., Saidha, S., Seigo, M., Calabresi, P. A., and Reich, D. S. (2013). Quantitative MRI demonstrates abnormality of the fornix and cingulum in multiple sclerosis. Mult. Scler. Int. 2013:838719. doi: 10.1155/2013/838719

Takei, K., Yamasue, H., Abe, O., Yamada, H., Inoue, H., Suga, M., et al. (2008). Disrupted integrity of the fornix is associated with impaired memory organization in schizophrenia. Schizophr. Res. 103, 52-61. doi: 10.1016/j.schres.2008.03.008

Tang, X., Yoshida, S., Hsu, J., Huisman, T. A., Faria, A. V., Oishi, K., et al. (2014). Multi-contrast multi-atlas parcellation of diffusion tensor imaging of the human brain. PLoS ONE 9:e96985. doi: 10.1371/journal.pone.0096985

Tate, D. F., and Bigler, E. D. (2000). Fornix and hippocampal atrophy in traumatic brain injury. Learn. Mem. 7, 442-446. doi: 10.1101/lm.33000

Teipel, S. J., Grothe, M., Lista, S., Toschi, N., Garaci, F. G., and Hampel, H. (2013). Relevance of magnetic resonance imaging for early detection and diagnosis of Alzheimer disease. Med. Clin. North Am. 97, 399-424. doi: 10.1016/j.mcna.2012.12.013

Tomaiuolo, F., Carlesimo, G. A., Di Paola, M., Petrides, M., Fera, F., Bonanni, R., et al. (2004). Gross morphology and morphometric sequelae in the hippocampus, fornix, and corpus callosum of patients with severe nonmissile traumatic brain injury without macroscopically detectable lesions: a T1 weighted MRI study. J. Neurol. Neurosurg. Psychiatry 75, 1314-1322. doi: 10.1136/jnnp.2003.017046

Vernooij, M. W., de Groot, M., van der Lugt, A., Ikram, M. A., Krestin, G. P., Hofman, A., et al. (2008). White matter atrophy and lesion formation explain the loss of structural integrity of white matter in aging. [Research Support, NonU.S. Gov't]. Neuroimage 43, 470-477. doi: 10.1016/j.neuroimage.2008.07.052

Vita, A., De Peri, L., Deste, G., and Sacchetti, E. (2012). Progressive loss of cortical gray matter in schizophrenia: a meta-analysis and meta-regression of longitudinal MRI studies. Transl. Psychiatry 2, e190 doi: 10.1038/tp.2012.116

Westerhausen, R., Kreuder, F., Dos Santos Sequeira, S., Walter, C., Woerner, W., Wittling, R. A., et al. (2004). Effects of handedness and gender on macro- and microstructure of the corpus callosum and its subregions: a combined highresolution and diffusion-tensor MRI study. Brain Res. Cogn. Brain Res. 21, 418-426. doi: 10.1016/j.cogbrainres.2004.07.002

White, T., Nelson, M., and Lim, K. O. (2008). Diffusion tensor imaging in psychiatric disorders. Top Magn. Reson. Imaging 19 97-109. doi: 10.1097/RMR.0b013e3181809fle

Yanike, M., and Ferrera, V. P. (2014). Representation of outcome risk and action in the anterior caudate nucleus. J. Neurosci. 34, 3279-3290. doi: 10.1523/JNEUROSCI.3818-13.2014

Yasmin, H., Aoki, S., Abe, O., Nakata, Y., Hayashi, N., Masutani, Y., et al. (2009). Tract-specific analysis of white matter pathways in healthy subjects: a pilot study using diffusion tensor MRI. Neuroradiology 51, 831-840. doi: 10.1007/s00234009-0580-1

Zahajszky, J., Dickey, C. C., McCarley, R. W., Fischer, I. A., Nestor, P., Kikinis, R., et al. (2001). A quantitative MR measure of the fornix in schizophrenia. Schizophr. Res. 47, 87-97. doi: 10.1016/S0920-9964(00)00051-7

Zahr, N. M., Rohlfing, T., Pfefferbaum, A., and Sullivan, E. V. (2009). Problem solving, working memory, and motor correlates of association and commissural fiber bundles in normal aging: a quantitative fiber tracking study. Neuroimage 44, 1050-1062. doi: 10.1016/j.neuroimage.2008.09.046

Zaitsev, M., Dold, C., Sakas, G., Hennig, J., and Speck, O. (2006). Magnetic resonance imaging of freely moving objects: prospective real-time motion 
correction using an external optical motion tracking system. Neuroimage 31, 1038-1050. doi: 10.1016/j.neuroimage.2006.01.039

Zgaljardic, D. J., Borod, J. C., Foldi, N. S., and Mattis, P. (2003). A review of the cognitive and behavioral sequelae of Parkinson's disease: relationship to frontostriatal circuitry. Cogn. Behav. Neurol. 16, 193-210. doi: 10.1097/00146965200312000-00001

Zheng, Z., Shemmassian, S., Wijekoon, C., Kim, W., Bookheimer, S. Y., and Pouratian, N. (2014). DTI correlates of distinct cognitive impairments in Parkinson's disease. Hum. Brain Mapp. 35, 1325-1333. doi: 10.1002/hbm.22256

Zhuang, L., Sachdev, P. S., Trollor, J. N., Reppermund, S., Kochan, N. A., Brodaty, H., et al. (2013). Microstructural white matter changes, not hippocampal atrophy, detect early amnestic mild cognitive impairment. PLoS ONE 8:e58887. doi: 10.1371/journal.pone.0058887

Zhuang, L., Wen, W., Zhu, W., Trollor, J., Kochan, N., Crawford, J., et al. (2010). White matter integrity in mild cognitive impairment: a tract-based spatial statistics study. Neuroimage 53, 16-25. doi: 10.1016/j.neuroimage.2010.05.068
Conflict of Interest Statement: The authors declare that the research was conducted in the absence of any commercial or financial relationships that could be construed as a potential conflict of interest.

Received: 18 July 2014; accepted: 14 December 2014; published online: 14 January 2015.

Citation: Douet $V$ and Chang L (2015) Fornix as an imaging marker for episodic memory deficits in healthy aging and in various neurological disorders. Front. Aging Neurosci. 6:343. doi: 10.3389/fnagi.2014.00343

This article was submitted to the journal Frontiers in Aging Neuroscience. Copyright (C) 2015 Douet and Chang. This is an open-access article distributed under the terms of the Creative Commons Attribution License (CC BY). The use, distribution or reproduction in other forums is permitted, provided the original author(s) or licensor are credited and that the original publication in this journal is cited, in accordance with accepted academic practice. No use, distribution or reproduction is permitted which does not comply with these terms. 